\title{
Quarterly Report on the Ferrocyanide Safety Program for the Period Ending September 30, 1995
}

Prepared for the U.S. Department of Energy Assistant Secretary for Environmental Management

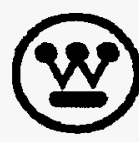

Westinghouse

Hanford Company Richland, Washington

Management and Operatione Contractor for the

U.S. Department of Energy under Contract DE-AC06-87RL10930

Approved for public release; distribution is unlimited 


\section{LECAL DISCLAMER}

This report was prepared as en acoount of work sponeored by en agency of the United States Government. Neither the United States Government nor any agency thereof, nor any of their omployees, nor any of their contractors, aubcontractors or their employees, makes any warranty, express or implied, or assumes any legal liability or responsibility for the accuracy, completeness, or any third party's use or the results of such use of any information, apparatus, product, or process disclosed, or represents that its use would not infringe privately owned rights. Reference herein to any specific cormmerciel product, process, or service by trade name, trademark, manufacturer, or otherwise, does not necessarily constitute or imply its ondorsement, recommendation, or favoring by the United States Government or any agency thereof or its contrectors or subcontractors. The views and opinione of authore expreseed herein do not nocesearily stato or reflect those of the United States Government or any egency thereof.

This report has been reproduced from tho best aveilable copy. Available in paper copy and microficho.

Available to the U.S. Department of Energy and its contractors from

U.S. Department of Energy

Office of Scientific and Technicel Information (OSTI)

P.O. Box 62

Oak Ridge, TN 37831

(615) 576-8401

Availeble to the public from the U.S. Department of Commerce Netional Technical Information Service (NTIS)

5285 Port Royal Road

Springfield, VA 22161

(703) $487-4650$

Printed in the United Statee of Americe 


\title{
Quarterly Report on the Ferrocyanide Safety Program for the Period Ending September 30, 1995
}

\author{
J. E. Meacham \\ R. J. Cash \\ G. T. Dukelow \\ Date Published \\ October 1995
}

Prepared for the U.S. Department of Energy

Assistant Secretary for Environmental Management

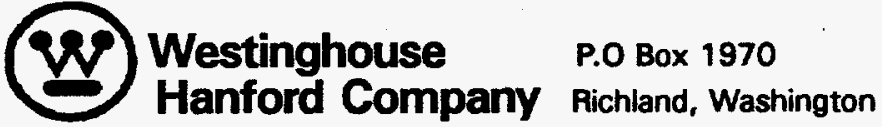

Management and Operations Contractor for the

U.S. Department of Energy under Contract DE-AC06-87RL10930

Approved for public release; distribution is unlimited 


\section{RELEASE AUTHORIZATION}

\section{Document Number: WHC-EP-0474-18}

Document Title: Quarterly Report on the Ferrocyanide Safety Program for the Period Ending September 30, 1995

Release Date: $\quad 10 / 31 / 95$

This document was reviewed following the procedures described in WHC-CM-3-4 and is:

APPROVED FOR PUBLIC RELEASE

WHC Information Release Administration Specialist:

4 Kara M. Broz




\section{DISCLAIMER}

Portions of this document may be illegible in electronic image products. Images are produced from the best available original document. 


\title{
QUARTERLY REPORT ON THE FERROCYANIDE SAFETY PROGRAM FOR THE PERIOD ENDING SEPTEMBER 30, 1995
}

\author{
J. E. Meacham \\ R. J. Cash \\ G. T. Dukelow
}

\begin{abstract}
This is the eighteenth quarterly report on the progress of activities addressing the Ferrocyanide Safety Issue associated with Hanford Site high-level radioactive waste tanks. Progress in the Ferrocyanide Safety Program is reviewed, including work addressing the six parts of Defense Nuclear Facilities Safety Board Recommendation 90-7 (FR 1990). All work activities are described in the revised program plan (DOE 1994b), and this report follows the same format presented there. A summary of the key events occurring this quarter is presented in Section 1.2. More detailed discussions of progress are located in Sections 2.0 through 4.0.
\end{abstract}


This page intentionally left blank. 


\section{CONTENTS}

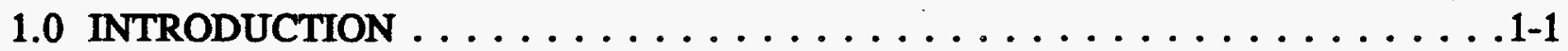

1.1 PURPOSE . . . . . . . . . . . . . . . . . .1-1

1.2 QUARTERLY HIGHLIGHTS $\ldots \ldots \ldots \ldots \ldots \ldots \ldots \ldots \ldots \ldots \ldots$

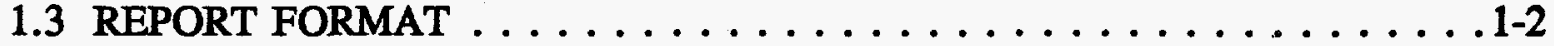

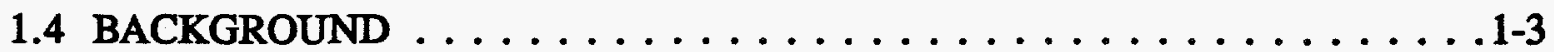

2.0 FERROCYANIDE SAFETY DOCUMENTATION $\ldots \ldots \ldots \ldots \ldots \ldots$. . . . .

3.0 ACTIONS TO COMPLETE DNFSB RECOMMENDATION 90-7 . . . . . . . . 3-1

3.1 ENHANCED TEMPERATURE MEASUREMENT $\ldots \ldots \ldots \ldots \ldots .1$

3.1.1 Instrument Trees . . . . . . . . . . . . . . . . 3-1

3.1.2 Upgrades to Existing Temperature Monitoring Instrumentation . . . . 3-2

3.1.3 Hot Spot Thermal Modeling $\ldots \ldots \ldots \ldots \ldots \ldots \ldots \ldots . . \ldots .3$

3.1.4 Infrared Scanning System . . . . . . . . . . . . . 3-4

3.1.5 Cooling System Requirements . . . . . . . . . . . . 3-4

3.2 CONTINUOUS TEMPERATURE MONITORING $\ldots \ldots \ldots \ldots \ldots \ldots \ldots$. . . . . . .

3.3 COVER GAS MODELING $\ldots \ldots \ldots \ldots \ldots \ldots \ldots \ldots \ldots \ldots . \ldots \ldots$

3.3.1 Interim Flammable Gas Monitoring . . . . . . . . . . 3-6

3.3.2 Continuous Gas Monitoring $\ldots \ldots \ldots \ldots \ldots \ldots \ldots \ldots \ldots \ldots$

3.4 FERROCYANIDE WASTE CHARACTERIZATION . . . . . . . . 3-8

3.4.1 Ferrocyanide Tank Waste Sampling and Analyses . . . . . . . . . 3-8

3.4.2 Estimation of Moisture Content . . . . . . . . . . . . . 3-15

3.4.3 Moisture Retention Properties of Ferrocyanide Sludge and Saltcake Simulants . . . . . . . . . . . . . . . . 3-19

3.5 CHEMICAL REACTION STUDIES . . . . . . . . . . . . . 3-21

3.5.1 Chemical Reaction Studies at Pacific Northwest Laboratory . . . . . 3-21

3.5.2 Preparation and Characterization of Ferrocyanide Simulants . . . . 3-24

3.6 EMERGENCY RESPONSE PLANNING . . . . . . . . . . 3-25

4.0 IMPLEMENTATION OF THE WYDEN AMENDMENT $\ldots \ldots \ldots \ldots \ldots \ldots$. . . . .

4.1 THE WATCH LIST $\ldots \ldots \ldots \ldots \ldots \ldots \ldots \ldots \ldots \ldots . \ldots \ldots$ 4-1

4.2 TEMPERATURE MONITORING $\ldots \ldots \ldots \ldots \ldots \ldots \ldots \ldots$ 4-3

4.3 PRESSURE MONITORING $\ldots \ldots \ldots \ldots \ldots \ldots \ldots \ldots \ldots . . \ldots \ldots$

5.0 PROGRAM SCHEDULES AND MILESTONES $\ldots \ldots \ldots \ldots \ldots \ldots$. . . . . $\ldots$

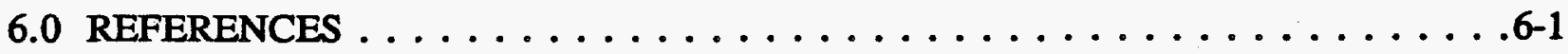

APPENDIX

FERROCYANIDE TANK INFORMATION SUMMMARY $\ldots \ldots \ldots \ldots \ldots$. . A-1 


\section{LIST OF FIGURES}

3-1 Influence of Added Metal Ions on Hydrolysis of In Farm Simulant at $90^{\circ} \mathrm{C}$ With an Applied Gamma Dose Rate of $1.07 \times 10^{5} \mathrm{Rad} / \mathrm{h} \ldots \ldots \ldots \ldots . . \ldots .23$

5-1 Ferrocyanide Waste Tank Safety Schedule . . . . . . . . . . . 5-2

\section{LIST OF TABLES}

A-1 Summary of Contents and Status of Ferrocyanide Tanks $\ldots \ldots \ldots \ldots \ldots$ A-3

A-2 Ferrocyanide Tank Vapor Sampling Summary $\ldots \ldots \ldots \ldots \ldots \ldots$. . . . . A-5 


\section{LIST OF TERMS}

ASA

$\mathrm{cal} / \mathrm{g}$

CASS

CTI

DNFSB

DOE

EA

EMI

FAI

FTIR

FY

g-mole

GAO

IR

ISB

$\mathrm{J} / \mathrm{g}$

$\mathrm{kW}$

LANL

LOW

NASA

NIR

PNL

ppmv

$\mathrm{Rad} / \mathrm{h}$

SA

SEM

SST

TC

TMACS

TNMOC

USQ

vol\%

VSS

WSU

wt\% accelerated safety assessment

calories per gram

Computer Automated Surveillance System

contact ignition criteria

Defense Nuclear Facilities Safety Board

U.S. Department of Energy

environmental assessment

electromagnetic induction

Fauske and Associates, Inc.

Fourier transform infrared

fiscal year

gram-mole

U.S. General Accounting Office

infrared

interim safety basis

joules per gram

kilowatt

Los Alamos National Laboratory

liquid observation well

National Aeronautics and Space Administration

near infrared

Pacific Northwest Laboratory

parts per million by volume

Rad per hour

safety assessment

scanning electron microscope/microscopy

single-shell tank

thermocouple

Tank Monitor and Control System

total non-methane organic carbon

unreviewed safety question

volume percent

Vapor Sampling System

Washington State University

weight percent 
This page intentionally left blank. 


\subsection{INTRODUCTION}

\subsection{PURPOSE}

This quarterly report provides a status of activities underway on the Ferrocyanide Safety Issue at the Hanford Site, including actions in response to Defense Nuclear Facilities Safety Board (DNFSB) Recommendation 90-7 (FR 1990). In March 1991, a DNFSB implementation plan (Cash 1991) responding to the six parts of Recommendation 90-7 was prepared and sent to the DNFSB. A ferrocyanide safety program plan addressing the total Ferrocyanide Safety Program, including the six parts of DNFSB Recommendation 90-7, was released in October 1994 (DOE 1994b). Activities in the program plan are underway or are completed, and the status of each is described in Sections 2.0 and 3.0 of this report.

\subsection{QUARTERLY HIGHLIGHTS}

- Instrument trees were installed in the last five ferrocyanide tanks (241-BY-103, 241-BY-108, 241-C-111, 241-TY-101, and 241-TY-103) this quarter. Sixteen new trees have been installed and temperatures in the ferrocyanide tanks are monitored using 33 trees. This completes this task activity and closes DNFSB Recommendation 90-7.1.

- All old and new instrument trees (33 trees total) in the 18 ferrocyanide tanks are connected to the Tank Monitor and Control System (TMACS) and are being monitored continuously. Temperature monitoring of the ferrocyanide tanks was turned over to Tank Farm Operations. All work for this task is complete, and DNFSB Recommendation 90-7.2 is closed.

- Multiple rotary-mode core samples were obtained from two ferrocyanide tanks this quarter (241-BY-108 and -BY-110). Six cores were obtained from tank 241-BY-108 and four cores were taken in tank 241-BY-110. Analyses of the core samples will be available early next quarter.

- Data interpretation reports were completed this quarter for tanks 241-C-108, -C-111, and -TY-104 (Sasaki 1995, Kelly 1995a, and Kelly 1995b). Because of delays in obtaining rotary-mode core samples from tank 241-BY-108, the report for that tank will be completed next quarter.

- A final report summarizing Fourier transform infrared (FTIR) work was issued this quarter (Rebagay et al. 1995), completing FTIR development work for the Ferrocyanide Safety Program.

- A report summarizing Mössbauer work was issued this quarter (Riedel 1995), completing Mössbauer development work for the Ferrocyanide Safety Program. 
- An annual report on scanning electron microscopy (SEM) results for fiscal year (FY) 1995, Scanning Electron Microscopic Analyses of Ferrocyanide Tank Wastes for the Ferrocyanide Safety Program - FY 1995 Report, WHC-SD-WM-RPT-194, Rev. 0, was prepared and issued this quarter (Callaway 1995). Work will be completed on this task in February 1996.

- Construction and testing of new dual-detector neutron moisture probes was completed, and the probes were used to obtain moisture data from ferrocyanide and organic Watch List tanks. This work completed the FY 1995 milestone for this task. Further work was transferred to the Organic Safety Program.

- The electromagnetic induction (EMI) probes were deployed in tanks 241-BY-104, -BY-106, -BY-107, -BY-111, -BY-112, -TY-103, -TX-118, -TX-114 (3 liquid observation wells [LOWs]), -S-105, and -S-106 this quarter. Results were promising, and the EMI development effort was transferred to the Organic Safety Program.

- Modeling of the moisture retention properties of saltcake and sludge waste was completed this quarter and a document issued (Simmons 1995). This report completes the moisture retention modeling for the Ferrocyanide Safety Program.

- A report on ferrocyanide degradation through hydrolysis and radiolysis was completed and released this quarter (Lilga et al. 1995). The report summarizes the results of aging experiments performed for the Ferrocyanide Safety Program.

- A report comparing the elemental concentrations of simulant and actual waste was released this quarter (Scheele 1995), completing the effort for this task.

- A report on the contact ignition criteria (CTI) for propagating reactions was released this quarter (Fauske et al. 1995a).

- A final report on chemical reactivity testing of simulants was completed this quarter (Fauske et al. 1995b). The report summarizes the results of propagation testing on ferrocyanide waste simulants at Fauske and Associates, Inc. (FAI). All ferrocyanide waste simulant experiments are completed, and no additional chemical reactive testing of simulants is planned.

\subsection{REPORT FORMAT}

Progress reports for activities under each of the six parts of DNFSB Recommendation 90-7 are arranged in the same order as the program plan (DOE 1994b). The arrangement also follows the same order provided in Recommendation 90-7. To report on progress, each part of the recommendation is repeated in italics, followed by paragraphs explaining the scope of work on each part or subpart of the recommendation. Subheadings for each task activity report the following: 
- Progress During Reporting Period

- Planned Work for Subsequent Months

- Problem Areas and Action Taken

- Milestone Status.

\subsection{BACKGROUND}

Since the mid-1940s, various high-level radioactive wastes from defense operations have accumulated at the Hanford Site in underground storage tanks. During the 1950s, additional tank storage space was required to support the defense mission. To obtain this additional storage volume within a short time period, and to minimize the need for constructing additional storage tanks, Hanford Site scientists developed a process to scavenge ${ }^{137} \mathrm{Cs}$ and ${ }^{90} \mathrm{Sr}$ from tank waste liquids. In implementing this process, approximately 140 metric tons (154 tons) of ferrocyanide were added to waste that was later routed to a number of Hanford Site single-shell tanks (SSTs) (Sloat 1954, 1955).

In the presence of oxidizing material such as sodium nitrate and/or nitrite, ferrocyanide can be made to react exothermically by heating it to high temperatures or by applying an electrical spark of sufficient energy (Cady 1993). However, fuel, oxidizers, and temperature are all important parameters. If fuel, oxidizers, or high temperatures (initiators) are not present in sufficient amounts, then a runaway or propagating reaction cannot occur.

In 1990, little was known about the potential hazards of a ferrocyanide-nitrate/nitrite reaction in Hanford Site SSTs. Because the safety envelope was not adequately defined by existing analyses, an inadequacy existed in the authorization basis ${ }^{1}$. That is, the existing safety analysis report (Smith 1986) and subsequent analyses such as the 1987 environmental impact statement (DOE 1987) did not adequately define the conditions necessary to preclude propagating reactions in the ferrocyanide waste; therefore, an unreviewed safety question (USQ) was declared (Deaton 1990).

Based on the knowledge gained from simulant studies, theoretical analyses, and analyses of actual waste samples, safety criteria were defined for the ferrocyanide waste (Postma et al. 1994a). These criteria were reviewed and accepted by outside reviewers and reviewers within the U.S. Department of Energy (DOE). The USQ was closed on March 1, 1994 by the DOE Assistant Secretary for Environmental Restoration and Waste Management (Sheridan 1994a).

${ }^{1}$ The U.S. Department of Energy (DOE) authorization basis characterizes the facility design basis and operational requirements for each nuclear facility. The authorization basis is described in documents such as facility safety analysis reports and other safety analyses, hazard classification documents, technical safety requirements, DOE-issued safety evaluation reports, and facility-specific commitments, such as safety assessments for specific tank operations and the Interim Safety Basis (Wagoner 1993). 
In September 1990, an ad hoc task force report (Kress et al. 1990) recommended that studies be performed to provide information on: (1) the potential for a ferrocyanide- nitrate/nitrite explosion; (2) the conditions necessary in the tanks to initiate an explosion; and (3) the potential consequences of such an occurrence. The U.S. General Accounting Office (GAO) advised the Secretary of Energy to implement these recommendations (Peach 1990). A closeout report addressing all three GAO recommendations was submitted to DOE in June 1994 (Payne 1994a). The closeout report summarizes the progress made on determining the potential for ferrocyanide reactions in Hanford Site ferrocyanide tanks, and the conditions necessary to sustain an exothermic ferrocyanide reaction.

In March 1989 (Nguyen 1989), based on process knowledge, process records, transfer records, and log books, 22 Hanford Site tanks were identified as potentially containing 1,000 gram-moles $\left(\mathrm{g}\right.$-moles) ${ }^{2}(211 \mathrm{~kg}$ [465 lb]) or more of ferrocyanide [as the $\mathrm{Fe}(\mathrm{CN})_{6}^{4}$ anion]. Two additional ferrocyanide tanks were identified in January 1991 (Borsheim and Cash 1991), increasing the number of ferrocyanide tanks to 24. To avert possible injury to personnel and damage to the facility or environment, strict controls were identified for these and other safety issue tanks in Operating Specifications for Watch List Tanks (WHC 1990). Tanks identified by this document (see WHC [1995] for the latest revision) have been commonly referred to as Watch List tanks. In October 1990 (Deaton 1990), the Ferrocyanide Safety Issue was declared a USQ (see Section 2.1) because the safety envelope for these tanks was no longer considered to be bounded by the existing safety analysis report (Smith 1986).

In November 1990, the Wyden Amendment (Public Law 101-510, Section 3137 [1990]) was enacted. This law required the identification of Hanford Site tanks that may have a serious potential for release of high-level waste (see Section 4.0). In February 1991 (Harmon 1991), the 24 ferrocyanide tanks were among the tanks identified, and were included in the subsequent July 1991 report to Congress (Watkins 1991) that responded to the Wyden Amendment. However, re-examination of the historical records (Borsheim and Simpson 1991) indicated that six of the 24 tanks did not contain the requisite $1,000 \mathrm{~g}$-moles of ferrocyanide. Therefore, these six tanks should not have been included on the Watch List nor identified in the response to the Wyden Amendment. The six tanks were subsequently removed from the Watch List (Anttonen 1993, Sheridan 1994b).

${ }^{2}$ The 1,000 g-moles criterion has since been replaced with a 115 calories per gram (cal/g) fuel concentration criterion. See Section 4.1 for discussion. 


\subsection{FERROCYANIDE SAFETY DOCUMENTATION}

The USQ process depends on an authorization basis that describes those aspects of the facility design basis and operational requirements relied on by DOE to authorize operation. The authorization basis is described in documents such as facility safety analysis reports and other safety analyses, hazard classification documents, technical safety requirements, DOE-issued safety evaluation reports, and facility-specific commitments, such as safety assessments (SAs), the interim safety basis (ISB), and the new accelerated safety assessment (ASA) scheduled for approval later this year. The potential hazards of a ferrocyanide-nitrate/ nitrite reaction were discovered to represent an inadequacy in the authorization basis (Smith 1986). The Ferrocyanide USQ was closed on March 1, 1994 by the DOE Assistant Secretary for Environmental Restoration and Waste Management (Sheridan 1994a). Progress on the remaining safety documentation for resolving the Ferrocyanide Safety Issue is reviewed in this section.

Safety and Environmental Assessments. SAs are documents prepared to provide the technical basis to assess the safety of a proposed activity and to provide proper controls to maintain safety. The SA and the accompanying environmental assessment (EA) for that operation provide the basis for DOE authorization of the proposed activities. SAs have been approved for headspace sampling of all ferrocyanide tanks, waste surface sampling, push-mode and rotary-mode core sampling, thermocouple (TC)/instrument tree installation in sound and assumed leaker tanks, and removal of pumpable liquid (interim stabilization). A generic EA covering all proposed operations in the tank farms was approved and a Finding of No Significant Impact issued by DOE (Gerton 1994). Approval of the generic EA provides adequate National Environmental Policy Act coverage for the planned Ferrocyanide Safety Program activities.

The authorization basis for intrusive tank operations was combined into one document, the ISB, which was approved in November 1993 (Wagoner 1993). Safety documentation concerning the ferrocyanide hazard was updated to reflect the approved ferrocyanide safety criteria and closure of the Ferrocyanide USQ. This information is also being incorporated into the ASA that will replace the ISB when approved by DOE.

Hazard Assessment. A report assessing the ferrocyanide waste tank hazards was issued in July 1992 (Grigsby et al. 1992). The report reviewed the understanding of the ferrocyanide hazard at that time, and presented an integrated evaluation and interpretation of historical data and then-available information. Additional data are now available on the potential for exothermic ferrocyanide reactions in Hanford Site SSTs. A final ferrocyanide hazard assessment will be submitted to DOE by July 31,1996 . Technical information from all Ferrocyanide Safety Program tasks will be compiled into this document, and the ISB (or ASA) will be amended accordingly. 
Ferrocyanide Program Plan. A ferrocyanide program plan was submitted to the DNFSB in December 1994 (O'Leary 1994). The program plan outlines activities planned to address DNFSB Recommendation 90-7, to meet the Wyden Amendment requirements (Public Law 101-510, Section 3137 [1990]), and to remove the remaining ferrocyanide tanks from the Watch List. All ferrocyanide program activities are scheduled to be completed by the end of FY 1997. However, an increased understanding of radiolytic and chemical degradation (aging) of ferrocyanide indicates that little ferrocyanide remains, and core sampling of all the tanks may not be required. Core sampling and analyses of only those tanks that bound aging (i.e., tanks with conditions least conducive to aging) could result in resolution of the Ferrocyanide Safety Issue much earlier and at a substantially reduced cost. As more core sample data become available, the need to sample all the ferrocyanide tanks will be reexamined.

- Milestone Status

- January 31, 1996. Westinghouse Hanford Company issues documentation supporting safety issue resolution for the four C Farm tanks, and recommends Ferrocyanide Safety Issue resolution for C Farm tanks.

- July 31, 1996. Westinghouse Hanford Company receives DOE approval for Ferrocyanide Safety Issue resolution for C Farm tanks.

- July 31, 1996. Westinghouse Hanford Company prepares and submits the final ferrocyanide hazard assessment for DOE approval.

- September 30, 1997. Westinghouse Hanford Company receives DOE approval for Ferrocyanide Safety Issue resolution. 


\subsection{ACTIONS TO COMPLETE DNFSB RECOMMENDATION 90-7}

This section follows the format of the program plan (DOE 1994b) and describes all work associated with the Ferrocyanide Safety Program. Where applicable, each task activity is described relative to the DNFSB Recommendation (90-7.1 through 90-7.6). The specific part of the recommendation is given, followed by a summary of activities underway to respond to that part of Recommendation 90-7 (if not already closed out).

\subsection{ENHANCED TEMPERATURE MEASUREMENT}

"Immediate steps should be taken to add instrumentation as necessary to the SSTs containing ferrocyanide that will establish whether hot spots exist or may develop in the future in the stored waste. The instrumentation should include, as a minimum, additional thermocouple trees. Trees should be introduced at several radial locations in all tanks containing substantial amounts of ferrocyanide, to measure the temperature as a function of elevation at these radii. The use of infrared techniques to survey the surface of waste in tanks should continue to be investigated as a priority matter, and on the assumption that this method will be found valuable, monitors based on it should be installed now in the ferrocyanide bearing tanks."

\subsubsection{Instrument Trees}

Work in several areas has developed a broader knowledge base that has warranted several changes in the approach to implementing this recommendation. Originally, it was planned to add several temperature measurement instruments to each tank. This plan was modified to ensure that at least one instrument tree with replaceable temperature-sensing elements is in each ferrocyanide tank. Additionally, at least two operational temperature-sensing elements should be in the waste to ensure a true temperature measurement, and one or more elements should be in the headspace.

The new data that have warranted this action include the following: (1) many of the TC elements in the existing trees have been returned to service, and measured temperatures are as expected; (2) thermal modeling to date (McLaren 1994a, 1994b) and an enhanced understanding of waste properties show that formation of hot spots in ferrocyanide tanks is not credible (Dickinson et al. 1993, Epstein et al. 1994); and (3) new calculations of tank heat content based on tank temperatures show lower values than previous estimates (Crowe et al. 1993, McLaren 1994a, 1994b).

There are two instrument trees in all but three ferrocyanide tanks (241-BY-106, -111 and -112). Tanks 241-BY-105 and -106 already contain instrument trees with replaceable temperature-sensing elements. Earlier, tanks 241-BY-111 and -112 had no operable instrument trees, and the waste temperatures were measured with a dedicated TC element 
installed into each tank's LOW. New instrument trees with replaceable temperature-sensing elements were installed in these two tanks in March 1993. The existing instrument trees in the ferrocyanide tanks will be monitored in addition to newly installed trees. The older trees are expected eventually to fail in a manner such that they cannot be repaired, and they will not be replaced.

- Progress During Reporting Period. Instrument trees were installed into the last five ferrocyanide tanks (241-BY-103, 241-BY-108, 241-C-111, 241-TY-101, and 241-TY-103) this quarter. The instrument trees were also connected to TMACS and acceptance tests were completed on August 24, 1995. All old and new instrument trees (33 trees total) in the 18 ferrocyanide tanks are now being monitored continuously. Temperature monitoring of the ferrocyanide tanks was turned over to Tank Farm Operations. All work is complete for this task and DNFSB Recommendation 90-7.1 is closed.

- Planned Work for Subsequent Months. None.

- Problem Areas and Action Taken. None.

- Milestone Status.

- September 30, 1995. Westinghouse Hanford Company completes installation of the last five instrument trees in assumed-leaker ferrocyanide tanks (Tri-Party Agreement [Ecology et al. 1994] Milestone M-40-02). The instrument trees were installed in the last five ferrocyanide tanks; all 33 instrument trees in the 18 ferrocyanide tanks are now installed, and temperatures are monitored continuously by TMACS as of August 24, 1995. The milestone is complete and DNFSB Recommendation 90-7.1 is closed.

\subsubsection{Upgrades to Existing Temperature Monitoring Instrumentation}

This task determined the operability and accuracy of previously installed TC elements in the original 24 ferrocyanide Watch List tanks. The original and newly installed instrument trees provide temperature measurements for the ferrocyanide tanks.

Field measurements were taken in 1991 on each TC element in the then-existing trees to determine the resistance and voltage across the junction and across each lead to ground. The exact condition of each TC element was determined by resistance and voltage measurements (Bussell 1992). This work was completed in FY 1991 with a total of 265 TC elements evaluated. Work in FY 1992 focused on repair and recovery of 92 TC elements that were found to be failed or marginal in performance. This task was completed in FY 1992. 
- Progress During Reporting Period. No progress was required or planned.

- Planned Work for Subsequent Months. None.

- Problem Areas and Actions Taken. None.

- Milestone Status. This task is complete.

\subsubsection{Hot Spot Thermal Modeling}

Radioactive materials decaying in Hanford Site waste tanks generate heat. An early concern, raised when the ferrocyanide tanks first became a safety issue, was whether an exothermic excursion and local propagation could occur within the ferrocyanide waste if a sufficient concentration of ferrocyanide and a high enough temperature were present. This task examined the available temperature data from the ferrocyanide tanks in order to determine the heat load and temperatures as a function of depth and radial location. Sensitivity and parametric analyses were included to determine the magnitude of a hot spot that would have to exist for the waste to reach propagation temperatures.

Heat load analyses and thermal characteristics were completed for all ferrocyanide tanks in FY 1994 (McLaren 1994a, 1994b). The maximum heat load of any ferrocyanide tank, assuming worst-case conditions for soil moisture and thermal conductivity, was below 4.2 kilowatts ( $\mathrm{kW}$ ). Nominal heat loads calculated by McLaren (1994a, 1994b) compared very favorably with those calculated independently in 1993 (Crowe et al. 1993). A dryout analysis was also completed and released in FY 1994 (Epstein et al. 1994). The report concluded that ferrocyanide sludge could not dry sufficiently to be chemically reactive during interim storage, either globally or locally. Dryout mechanisms evaluated included global evaporation, removal of liquid by leakage or pumping, boiling as a result of hot spots, and enhanced surface evaporation from hot spots. All activities were completed for this task in FY 1994.

- Progress During the Reporting Period. None.

- Planned Work for Subsequent Months. None.

- Problem Areas and Action Taken. None.

- Milestone Status. This task is complete. 


\subsubsection{Infrared Scanning System}

Infrared (IR) scanning systems are commercially available from numerous vendors. These systems are sensitive to changes of $\pm 0.3{ }^{\circ} \mathrm{C}$ or less under ideal conditions and offer promise for mapping surface temperature profiles in the ferrocyanide tanks. Thermal modeling performed on ferrocyanide tank 241-BY-104 (McLaren 1993) suggested that if hot spots with temperatures of concern are possible, surface temperature differences might be great enough to be detected by IR mapping.

A position paper on the credibility of hot spots and the need for further IR scanning was issued in April 1993 (Dickinson et al. 1993). Further analyses have been performed to assess potential dryout of the ferrocyanide waste (Epstein et al. 1994). These reports examined potential mechanisms for forming hot spots. Analyses indicate that hot spots are not credible in ferrocyanide tanks. Based on these analyses, Westinghouse Hanford Company recommended that no further planning be pursued for IR scans for the purpose of detecting hot spots.

- Progress During the Reporting Period. None.

- Planned Work for Subsequent Months. None.

- Problem Areas and Action Taken. None.

- Milestone Status. This task is complete.

\subsubsection{Cooling System Requirements}

The program plan for resolution of the Ferrocyanide Safety Issue (DOE 1994b) provided actions that would be taken to cool the ferrocyanide tanks if such cooling were to be determined necessary. Several tentative milestones, identified below, were established for use if a cooling system(s) were to be required. The concern at the time was that increasing temperatures could lead to loss of moisture within the ferrocyanide waste matrix. Immediate emergency actions that would be taken if increased temperatures were to occur are described in the Action Plan for Response to Abnormal Conditions in Hanford Site Radioactive Waste Tanks Containing Ferrocyanide (Fowler 1994). Types of cooling systems might include, but are not limited to, the following: (1) forced ventilation of the tank, using an existing or new exhauster system; (2) air conditioning the air to the tank; (3) adding humid air or mist; and (4) adding water to the tank.

Based on the historical database, results of samples from seven ferrocyanide tanks, and results from the Pacific Northwest Laboratory (PNL) aging test activity, none of the 18 ferrocyanide tanks contain a high enough concentration of ferrocyanide for a propagating 
reaction to occur. Because dryout of the waste under the present storage conditions (Epstein et al. 1994) is not credible, a special cooling system for the ferrocyanide tanks is not considered necessary. No further work on this task is planned.

- Progress During the Reporting Period. None.

- Planned Work for Subsequent Months. None.

- Problem Areas and Action Taken. None.

- Milestones Status. None.

\subsection{CONTINUOUS TEMPERATURE MONITORING}

"The temperature sensors referred to above [Recommendation 90-7.1] should have continuous recorded readouts and alarms that would signal at a permanently manned location any abnormally high temperatures and any failed temperature instrumentation."

This task provides continuous monitoring of presently installed (and operable) temperature-sensing elements for the ferrocyanide tanks. New instrument trees will be connected to the system as they are installed into each tank, resulting in continuous temperature monitoring in the ferrocyanide tanks. All data are collected automatically at the continuously manned Computer Automated Surveillance System (CASS) Operator Control Station. The monitoring system is independent of the CASS and is capable of displaying data to an operator on request. Trend data on selected points are available for display in numeric or graphic form.

The TMACS system, which became operational in September 1991, has the capacity to assign alarms for a change in the value of any temperature point. Alarms, if they occur, trigger an audible annunciator and are logged immediately to hard copy. An alarm summary display provides a list of the most recent alarms in order of occurrence. Each alarm can be identified by point and time of occurrence. Operator acknowledgement of the alarm will silence the audible annunciator. Signal conditioning and multiplexing are performed locally at each tank, eliminating the need to transmit low-level signals to the tank farm boundary and reducing cable runs. Electronic noise, extension wire corrosion, and thermal gradients are also reduced.

- Progress During Reporting Period. The last instrument trees in the ferrocyanide tanks were connected to TMACS this quarter. Temperatures for all 33 instrument trees in the 18 ferrocyanide tanks are being monitored continuously. Completion of this task closes DNFSB Recommendation 90-7.2.

- Planned Work For Subsequent Months. None. 
- Problem Areas and Action Taken. None.

- Milestone Status.

- September 30, 1995. Westinghouse Hanford Company completes TMACS connections for all installed instrument trees in ferrocyanide tanks. All the ferrocyanide tanks are connected to TMACS and are monitored continuously. This completes Tri-Party Agreement Milestone M-40-02 and also closes out DNFSB Recommendation 90-7.2.

\subsection{COVER GAS MODELING}

"Instrumentation should also be installed to monitor the composition of cover gas in the tanks, to establish if flammable gas is present."

\subsubsection{Interim Flammable Gas Monitoring}

The effort to conduct flammable and toxic gas monitoring and analyses in the ferrocyanide tanks is continuing. Most of this effort was transferred to the Tank Vapor Monitoring Program, which is coordinating interim gas monitoring of the ferrocyanide tanks and tanks involved with the tank vapor program. Tank headspaces are measured for flammability using a commercial combustible gas monitor (calibrated with pentane gas), and are monitored for potential toxic gases using an organic vapor monitor and Dräger ${ }^{3}$ tubes. Headspace characterization of all the Hanford Site high-level waste tanks is continuing using sorbent tubes placed on the end of tubes lowered into the headspace and SUMMA ${ }^{4}$ canisters that collect gas samples topside. The initial headspace sampling was done in several tank locations (i.e., from two widely separated risers) and at three elevations in the headspace. Reviews of sampling data and modeling (Wood 1992, Claybrook and Wood 1994, Postma et al. 1994b) indicate that the headspace is well mixed and that sampling from one riser at one elevation is adequate.

- Progress During Reporting Period. Headspace sampling of all 18 ferrocyanide tanks was completed last quarter. Table A-2 in the Appendix summarizes the results. Headspace sampling of the ferrocyanide tanks will continue on a periodic basis as part of the Tank Vapor Monitoring Program.

- Planned Work For Subsequent Months. None.

- Problem Areas and Actions Taken. None.

\footnotetext{
${ }^{3}$ Trademark of Drägerwerk Aktiengesellschaft, Inc., Lubeck; Germany; also National Draeger, Inc., Pittsburgh, Pennsylvania.

${ }^{4}$ Trademark of Molectrics, Inc., Cleveland, Ohio.
} 
- Milestone Status

- September 30, 1995. Westinghouse Hanford Company completes headspace sampling of remaining ferrocyanide tanks. All ferrocyanide tank headspaces have been sampled and analyzed, completing this milestone and closing out DNFSB Recommendation 90-7.3. Tri-Party Agreement Milestone M-40-03 (complete headspace characterization for all ferrocyanide Watch List tanks by November 30 , 1995) will be completed when a letter documenting completion of this Tri-Party Agreement milestone is sent to the Washington State Department of Ecology and the U.S. Environmental Protection Agency next quarter.

\subsubsection{Continuous Gas Monitoring}

The possibility that localized concentrations or stratification of gases exist in the tanks was evaluated. A modeling study was conducted to determine airflow patterns in the headspace of tank 241-C-109 and evaluate the amount of mixing and the local gas concentrations that could occur. The study revealed that the gases in the tank are well mixed and follow Graham's law for gaseous diffusion; therefore, an analysis of a second tank was considered unnecessary (Wood 1992). Studies completed since that time (Claybrook and Wood 1994, Postma et al. 1994b) also confirm that conclusion.

The need for continuous gas monitoring was addressed in a report that also assessed the potential for cyclic venting and the possibility of accumulating flammable gases (Fowler and Graves 1994). The report concluded that continuous flammable gas monitoring in ferrocyanide tanks is not warranted based on: (1) the low concentration of flammable gases found to date; (2) anticipated low ferrocyanide concentrations because of waste aging; (3) analytical results from tanks 241-C-109 and -112 showing that the fuel concentration in the tanks is much lower than postulated by flowsheet values and operating records; and (4) calculations of hydrogen accumulation using realistic generation values and passive ventilation assumptions. Vapor sampling of all 18 ferrocyanide tanks has corroborated that flammable gas concentrations in the ferrocyanide tanks are too low to be of concern. No further activities are planned for this task.

- Progress During Reporting Period. None.

- Planned Work For Subsequent Months. This task is complete. DOE has concurred that no continuous gas monitoring is required (O'Leary 1994).

- Problem Areas and Actions Taken. None.

- Milestone Status. None 


\subsection{FERROCYANIDE WASTE CHARACTERIZATION}

"The program of sampling the contents of these tanks should be greatly accelerated. The proposed schedule whereby analysis of two core samples from each single-shell tank is to be completed by September 1998 is seriously inadequate in light of the uncertainties as to safety of these tanks. Furthermore, additional samples are required at several radii and at a range of elevations for the tanks containing substantial amounts of ferrocyanide."

Characterization of the waste in the ferrocyanide tanks is necessary to: (1) guide further chemical reaction studies with the ferrocyanide waste simulants; (2) determine actual waste chemical and physical properties; (3) determine how the ferrocyanide waste can be safely stored until retrieval and disposal actions are completed; and (4) apply the study results to the final remediation of the waste. This information is necessary to resolve the Ferrocyanide Safety Issue.

The important reactive materials present in the ferrocyanide tanks are fuel (ferrocyanides, sulfides, and reduced carbon species such as organic complexants), oxidants (nitrates and nitrites), and inerts or diluents (including phosphates, aluminates, sulfates, carbonates, oxides, and hydroxides). The location of fission products such as ${ }^{137} \mathrm{Cs}$ and ${ }^{90} \mathrm{Sr}$ is important because these products are heat sources and potential source terms in postulated radiological releases from a hypothetical ferrocyanide reaction. The water content of the waste is very important because water's high heat capacity and heat of vaporization make it an effective inerting material. Water can prevent a sustained combustion or a propagating reaction; wet ferrocyanide material would require drying before it could react or propagate.

\subsubsection{Ferrocyanide Tank Waste Sampling and Analyses}

Tank Sampling. Rotary-mode and push-mode sampling capabilities and auger surface sampling are used to obtain waste samples from the Watch List tanks. Tanks without saltcake and with relatively soft waste solids can be sampled by the push-mode method. If a hard saltcake layer is present, rotary-mode sampling can be used. Auger sampling may also be used if the depth of waste is nominally less than $60 \mathrm{~cm}$.

Each core consists of several 48-cm segments (or portions thereof) depending on the depth of the waste in the tank. The sludge layer in these cores is divided into four $12-\mathrm{cm}$ subsegments for each $48-\mathrm{cm}$ segment. If the tank contains a saltcake layer, the saltcake segments will be divided into only two subsegments. Process flowsheet knowledge, tank historical data, and results obtained from tests with ferrocyanide sludge simulants are used to supplement the analytical results from core sampling.

The priority for sampling ferrocyanide tanks was changed to reflect the need to determine the reactive properties of the contents. In response to DNFSB Recommendation 93-5 (DOE 1994a) to expedite sampling and analyses required to address safety issues in the Hanford Site Watch List tanks, the analysis plans for future ferrocyanide tank core samples (and the 
plans for other Watch List tanks) were revised. The Watch List tanks were given priority for core sampling, and the number of required analytes was reduced. Analyte selection was refocused primarily on safety-related properties.

- Progress During Reporting Period. Multiple rotary-mode core samples were obtained from two ferrocyanide tanks this quarter (241-BY-108 and -BY-110). Six cores were obtained from 241-BY-108 and four cores were taken in tank 241-BY-110, meeting the requirements specified in the Ferrocyanide Data Quality Objectives (DQO) document (Meacham et al. 1995a). Analyses of the core samples will be available early next quarter.

- Planned Work For Subsequent Months. The next ferrocyanide tanks to be sampled are 241-BY-104, -TY-103, and -TX-118. Although tanks 241-BY-105 and -BY-106 are currently listed on the schedule for sampling next quarter, it is doubtful that sampling will be completed in these tanks (see Problem Areas below). A tank characterization (data interpretation) report will be prepared and issued next quarter for tank 241-BY-108.

- Problem Areas and Actions Taken. The drill string in riser 12B of tank 241-BY-110 was bent during rotary-mode sampling, and the drill string remains in the tank. A tool for extracting the failed drill string (the Sliding Wedge Cylinder) was designed, built, and tested in the laboratory. The drill string will be extracted next quarter.

Monitoring of the waste height in ferrocyanide tanks 241-BY-103, -BY-105, and $-\mathrm{BY}-106$, indicates possible slurry growth, and the waste in these tanks may contain trapped gas. Consequently, flammable gas Watch List controls were imposed on these three tanks as sound management practice. Because an SA for rotary-mode sampling of a flammable gas tank has not yet been approved, sampling of tanks 241-BY-103, -BY-105, and -BY-106 has been delayed. A more detailed evaluation to determine if 241-BY-103, -BY-105, and -BY-106 are indeed flammable gas tanks is underway. Concurrently, an SA is being drafted for rotary-mode sampling a flammable gas tank.

Because of these problems, it will not be possible to complete the milestone dates as shown below for FY 1996.

- Milestone Status.

- June 30, 1995. Westinghouse Hanford Company obtains core and/or auger samples from four ferrocyanide tanks. This milestone was completed this quarter. Samples were obtained from tanks 241-C-108, -C-111, and -TY-104 last quarter. Tank 241-BY-108 was sampled this quarter. 
- September 30, 1995. Westinghouse Hanford Company completes data interpretation reports, available for public release, for four ferrocyanide tanks. Three reports for tanks 241-C-108, -C-111, and -TY-104 were completed this quarter (Sasaki 1995, Kelly 1995a, and Kelly 1995b). Because of delays in obtaining rotary-mode core samples from tank 241-BY-108, the fourth report will be completed next quarter.

- December 31, 1995. Westinghouse Hanford Company obtains core samples from five additional ferrocyanide tanks. The five additional tanks are scheduled for sampling in 1995. However, completion of this milestone depends on the timeliness of rotary-mode core sampling. This date will not be met as planned because of the delay in sampling tanks 241-BY-103, -BY-105, and -BY-106, as mentioned above.

- March 31, 1996. Westinghouse Hanford Company completes data interpretation reports, available for public release, for five ferrocyanide tanks. This milestone date will not be met because of the delays encountered in rotary-mode sampling some of the ferrocyanide tanks.

- July 31, 1996. Westinghouse Hanford Company obtains core samples from the remaining ferrocyanide tanks. This milestone date will not be met because of the delays encountered in rotary-mode sampling some of the ferrocyanide tanks.

- October 31, 1996. Westinghouse Hanford Company completes data interpretation reports, available for public release, for the remaining ferrocyanide tanks. It is doubtful that this milestone can be met because of the current delay in obtaining core samples from some of the ferrocyanide tanks.

Infrared Spectroscopy Analyses. The collection of near-infrared (NIR) spectra from archived waste tank waste core samples with various chemical matrices using a Fourier transform infrared (FTIR) spectrometry-based fiber optics method is continuing. Calibration of the method using nonradioactive simulants that mimic the actual composition of tank waste was started.

Based on preliminary results, the fiber optic probe fabricated by the Westinghouse Savannah River Laboratory in Aiken, South Carolina, could provide sufficient throughput to perform multi-component analyses on diffusely-reflected mixed waste. The probe has a single detector fiber surrounded by six infrared source fibers beveled toward the detector fiber (six around one configuration). This cone-face design causes all fiber optic fields to cross at a fixed distance from the probe surface, forming an effective optical diameter of about 1 millimeter. The most pressing concern in performing quantitative spectral measurements with this probe is the difficulty of obtaining reproducible data because of the inhomogeneous sample surfaces. The small optical diameter of this probe makes it especially sensitive to surface inhomogeneities. 
To improve sensitivity, design efforts have focused on reducing interference fringes and stray incident infrared light. Substantial improvement in sensitivity can be made through optical or experimental suppression of the interference fringes and elimination of stray light. A new diffuse-reflectance probe, consisting of a collimator, a hollow metallic light guide, focusing optics, and a sapphire window, was purchased in mid-July 1995. The probe was interfaced to a new 80 -fiber bifurcated fused silica bundle (40-fiber bundle for the infrared source and 40-fiber bundle for the detector assembly in a "salt and pepper" configuration) that can be detached from the fiber bundle for cleaning or replacement.

- Progress During Reporting Period. Spectra collected by diffuse absorbance and by mid-infrared photoacoustic spectroscopy were compared this quarter to determine which method had better resolution. Tests were conducted on two oven-dried simulants, 241-BY-104 and -SY-101. Results indicate that the diffuse reflectance spectra have more distinct bands for chemical structure elucidation than the photoacoustic spectra. A final report summarizing FTIR work was issued this quarter (Rebagay et al. 1995). This completes the FTIR development work for the Ferrocyanide Safety Program.

- Planned Work For Subsequent Months. None.

- Problem Areas and Actions Taken. None.

- Milestone Status.

- September 30, 1995. Westinghouse Hanford Company issues a final report on FTIR technology development. A final report on FTIR technology development was released this quarter (Rebagay et al. 1995).

Mössbauer Spectroscopy. A small task on Mössbauer spectroscopy is investigating the physical and chemical nature of iron within ferrocyanide tank waste. The National Aeronautics and Space Administration (NASA) has developed a miniaturized Mössbauer spectrometer that is small enough to perform elevation scans in the LOWs. Iron is a major constituent of ferrocyanide waste, and information about its location and composition in the tanks supports safe interim storage and eventual retrieval of the waste.

Mössbauer spectroscopy can provide the valence state of iron as well as specific coordination chemistry for the iron atom. That is, Mössbauer spectroscopy can see differences in anions surrounding the iron cation in a stable crystalline structure and distinguish between different iron-based minerals. A recent development in this type of spectroscopy is the use of reflectance rather than transmission spectroscopy, thus allowing information to be gained in situ. Mössbauer spectroscopy can distinguish between ferrocyanide and ferricyanide complexes and almost any iron compound that might exist within tank waste. By knowing the iron concentration and species as a function of elevation in a given tank, it should be possible to determine how much aging has occurred within the waste. 
The Mössbauer program represents a cooperative venture between Westinghouse Hanford Company, DOE, and NASA. The contact at NASA is Dr. Richard Morris at the Johnson Space Center in Houston, Texas.

- Progress During Reporting Period. The Mössbauer spectrometer was tested on radioactive materials inside the 222-S Hot Cells Area. Preliminary efforts to use actual tank core material met with mixed success. The detector was unaffected by the high radiation fields, but resolution difficulties were experienced. A report summarizing Mössbauer work was issued this quarter (Riedel 1995). This completes the Mössbauer development work for the Ferrocyanide Safety Program.

- Planned Work for Subsequent Months. None.

- Problem Areas and Actions Taken. The hot cell results showed the need for better signal discrimination. Cooling the detector and adjusting its window to a more narrow setting should result in increased sensitivity.

- Milestone Status.

- July 29, 1995. Westinghouse Hanford Company initiates hot cell testing of the Mössbauer tank probe using ferrocyanide tank waste samples. This milestone was completed this quarter.

- September 30, 1995. Westinghouse Hanford Company completes an in-tank test of the Mössbauer probe in a LOW in one of the ferrocyanide tanks. Sampling of ferrocyanide tanks has shown low remaining ferrocyanide concentrations. In-tank testing of the Mössbauer probe would have little benefit. Therefore, this milestone was deleted and notification of this change is hereby provided in accordance with Section 3.7 of the program plan (DOE 1994b).

- September 30, 1995. Westinghouse Hanford Company issues a report, available for public distribution, on the Mössbauer spectroscopy program results for FY 1995. This milestone was completed on schedule (Riedel 1995).

Scanning Electron Microscopy. Chemical and physical properties of ferrocyanide tank waste are being determined to accurately assess the waste for safety and inventory purposes. Analyses indicating the presence or absence of key chemical components--including $\mathrm{CN}^{-}, \mathrm{Na}$, $\mathrm{Fe}, \mathrm{Ni}$, and $\mathrm{Cs}-\mathrm{can}$ be used to characterize the tank waste and to assess whether the waste can be stored safely until retrieval for final disposal. Measurements that allow examination of possible correlations of chemical composition and physical properties, such as particle and crystallite size, may provide additional information on how the waste may have changed with time and facilitate comparisons of real waste properties with those determined earlier for waste simulants. 
Scanning electron microscopy (SEM), coupled with backscattered electron detection and energy dispersive X-ray spectroscopy, provides a method uniquely capable of providing particle size, chemical composition, and particle morphology information in a single measurement. Recent developments in instrumentation computer control, digital data acquisition, and light element X-ray detection have significantly enhanced the utility of this technology for particle characterization applications. Further refinements in integrated computer software and firmware now enable rapid collection, processing, and storage of large volumes of chemical and numerical data. Through these instrumentation and data processing enhancements, SEM micro-characterization has evolved into a new and potentially powerful methodology for the characterization of ferrocyanide and organic tank waste.

- Progress During Reporting Period. Unacceptable performance of the R. J. Lee Personal SEM ${ }^{1}$ system continued to hinder program progress. During two site visits, the SEM vacuum system, the column hardware, console hardware and control electronics were reworked. During the past fiscal quarter, both the manual and motorized specimen stage systems were returned to the vendor's facility for repair, and updated versions of several software programs were acquired in order to correct operational deficiencies. Vacuum system, vibrational noise and motorized stage operation problems are resolved. Two software issues and repair of the manual specimen stage remain outstanding.

A vibration dampening system was specified and installed on the SEM system. Tests verified that the dampening mounts significantly reduced the impact of groundpropagated vibrational noise on SEM performance. The pneumatic mounts should be of particular value when the SEM system is transferred to the radiological sample analysis trailer.

A trailer was acquired and is being configured to support SEM analysis of radioactive ferrocyanide tank waste samples. This trailer will be a posted radiological zone located at the 600 Area Weather Station. Appropriate furnishings, support equipment and outfitting supplies were identified in the Westinghouse Hanford Company excess pool or acquired through local vendors. Outfitting of the SEM trailer is proceeding.

Transfer of SEM specimen preparation equipment into the 222-S Laboratory facility began. Preparation equipment required to complete installation of a specimen preparation station within a 222-S radiological hood was identified and ordered. Requests for supplemental dosimetry required for these activities in the 222-S facility were completed and submitted.

${ }^{1}$ Trademark of R. J. Lee Instruments Ltd., Trafford, Pennsylvania. 
Procurement of the SEM system upgrade package was completed. These upgrades are to be installed in October 1995 and will enhance: (1) SEM data transfer and archiving capabilities; (2) SEM semi-quantitative elemental analysis capabilities; and (3) SEM analysis data processing and presentation options.

Purchase requisitions were completed and submitted for all additional SEM operational supplies, analysis consumables and specimen preparation equipment anticipated to be required for the targeted SEM micro-characterization activities. Delivery of all items should be completed by October 31 .

An annual report on SEM program results for FY 1995, Scanning Electron Microscopic Analyses of Ferrocyanide Tank Wastes for the Ferrocyanide Safety Program - FY 1995 Report, WHC-SD-WM-RPT-194, Rev. 0, was prepared and issued this quarter (Callaway 1995).

- Planned Work For Subsequent Months. Work in the SEM program will be carried forward into FY 1996. The target date for completion of SEM-based micro-characterization of a ferrocyanide tank core sample is February 29, 1996. A Westinghouse Hanford Company SEM program report, available for public release, will be issued on March 31, 1996.

- Problem Areas and Actions Taken. System failures and performance deficiencies of the R. J. Lee Personal SEM ${ }^{\mathrm{Tx}}$ continue to delay activity milestones. In an August 16 meeting with Dr. R. J. Lee, President of the R. J. Lee Group, Inc., the SEM program cognizant scientist was assured that immediate action would be taken to resolve outstanding SEM performance issues. Several issues were subsequently resolved during the vendor's September 5-15 visit. Remaining hardware and software issues are currently being addressed at the vendor's facility.

Delay in locating a facility suitable for SEM analysis of radioactive tank waste specimens has been a major problem, but is now be resolved. Two trailer facilities were located that can accommodate SEM analyses of the radioactive ferrocyanide tank wastes. Outfitting of one trailer is proceeding while final evaluation of the alternate trailer is made.

Two members of the Hanford Technical Services group who were attached to the SEM program in support of specimen preparation, trailer outfitting and radiological concerns tasks were included in the recent (September 26, 1995) Hanford Site Reduction of Force. Efforts are underway to identify replacement personnel in order to mitigate the impact of these loses on program targets. 
- Milestone Status.

- May 31, 1995. Westinghouse Hanford Company installs and completes operational acceptance tests on SEM system. Operational problems continue with the R. J. Lee Personal SEM ${ }^{\mathrm{m}}$ system. Several issues were resolved during the vendor's September 5-15 visit and the balance of the outstanding issues are currently being addressed in the vendor's facility. Operational acceptance tests will be completed two weeks after final resolution of the SEM performance issues.

- September 29, 1995. Westinghouse Hanford Company issues a report, available for public release, on SEM program results for FY 1995. A report was issued on schedule this quarter (Callaway 1995).

- March 31, 1995. Westinghouse Hanford Company issues a final report on SEM technology development.

\subsubsection{Estimation of Moisture Content}

Methods for determining moisture concentrations in ferrocyanide waste tanks are being developed using sample data analyses and available surveillance systems. This work is an increase in scope from the original implementation plan (Cash 1991), which did not examine moisture monitoring. Two in situ moisture monitoring technologies are currently being investigated by the Ferrocyanide Safety Program, neutron diffusion and electromagnetic induction (EMI). Initial development of NIR spectroscopy was completed in FY 1994 (Reich et al. 1994) at the University of Washington Center for Process Analytical Chemistry. This surface moisture monitoring technology will not be developed further by the Ferrocyanide Safety Program. Additional moisture monitoring technologies, such as copper foil activation and fission chamber in a cone penetrometer, are being evaluated by other programs. A report examining moisture monitoring technologies was completed in April 1993 (Meacham et al. 1993).

Neutron Diffusion. Well-logging techniques, coupled with computer modeling, were developed and applied to an existing neutron probe to determine information about moisture levels, material interfaces, and other waste characteristics in the ferrocyanide tanks. Using the knowledge gained from computer modeling, in situ measurements, and experimental calibration data with the current in-tank liquid level neutron probe (Watson 1993), prototype moisture measurement neutron probes were developed. This system consists of three neutron probes: a near-field thermal neutron probe, a far-field thermal neutron probe, and a far-field epithermal neutron probe. This improved system would primarily be used to determine the axial moisture concentration profile within the ferrocyanide tanks. 
Moisture measurement using neutron diffusion is an established technology. The technique uses a neutron source and one or more neutron detectors. The thermal neutrons reaching a detector originate as fast neutrons from the source and are slowed or absorbed by the medium. Because hydrogen atoms are effective at slowing down neutrons, the detector response is a strong function of the surrounding moisture concentration.

Two methods are generally used in the measurement of moisture concentration around wells using neutron diffusion. The first method, the moisture gauge, has a short source-to-detector spacing (near field) on the order of 0 to $10 \mathrm{~cm}$. The response of a moisture gauge is characterized by an increase in detector response with increasing moisture concentration of the surrounding medium. The second method, the neutron log, often has two detectors with longer source-to-detector spacings: 20 to $50 \mathrm{~cm}$ (far field). The detectors in a neutron log arrangement exhibit a decreased response to increased moisture concentrations. The detector placed at the shorter spacing is used to correct the response of the longer-spaced detector for borehole effects.

Tank moisture measurements are taken from within LOWs. The LOWs are permanently installed sealed pipes that extend from the riser top through the tank waste to near the tank bottom. The LOWs allow axial information about the surrounding waste materials to be obtained using certain detectors.

- Progress During Reporting Period. Construction and testing of new dual-detector neutron moisture probes are complete, and the probes have been used to obtain moisture data from ferrocyanide and organic Watch List waste tanks. These probes provide enhanced responses to moisture changes and enable WHC to make better interpretations of moisture responses from regions of the tanks where an air gap exists between the LOW and surrounding saltcake. These probes have been deployed and used to obtain data from 14 LOWs in 12 tanks. A letter report was issued on August 31, 1995 to meet the TWRS milestone to "Implement Moisture Monitoring for Ferrocyanide Tanks with Existing LOWs Using Dual Neutron Probe." This report was transmitted to DOE in September (Lipke 1995b).

The TMAD code, designed to evaluate the neutron and EMI probe scan data and predict moisture content, has been completed. The code has been tested, validated, and applied to tank scans obtained with the prototype neutron probes. A letter report was transmitted to DOE in August 1995 that describes the moisture interpretation results provided by this preliminary data (Lipke 1995a). For tank 241-BY-104, the moisture interpretation predicted in the saltcake is in very good agreement with available analyses from auger samples (Beck 1992). Complete software quality assurance documentation has been produced for the code, including: project management plan; system design description, verification and validation report; and a code user's manual (Finfrock 1995a, 1995b, 1995c, and 1995d). This interpretation code will be applied to the data gathered with the new dual-detector neutron probes once the model-produced interpretation libraries are completed for these probes. 
A new liquid observation well has been designed to accommodate the deployment of gamma, neutron, and electromagnetic induction probes and to interface with the existing tank structure and environment. An improved method of LOW installation reduces the water introduced to the tank and lessens the chance that a large annulus will form in the waste around the LOW. New LOWs were needed because the original type contained large amounts of neutron absorbers and has not provided the needed strength to survive the conditions in all tanks. Test results of the S-type fiberglass probe under a simulated waste tank environment were satisfactory and have been documented (Parra 1995). Two types of S-type fiberglass materials were evaluated for use as the LOW casing. The durability of the designed joints and interfaces for the LOW tubes was also tested. The selected LOW material and design should provide superior strength, durability, and insertion capability while enabling more accurate moisture measurements to be made with all probes under development.

The initial design and prototype tests have been completed for a new surface moisture measurement neutron probe. A modeling and test report documenting the baseline design for the probe is being written. This probe will be lowered directly onto the waste surface in order to obtain moisture data from the waste surface. The deployment system will allow positioning of the neutron probe anywhere within a 2-meter radius. Modeling and test results confirm that the probe should be able to interrogate three different depths, up to $15 \mathrm{~cm}$, below the waste surface so that information about the moisture concentration as a function of depth will be provided. The design of a dedicated data acquisition system for both the surface and LOW neutron probes has been completed and assembly of the system is underway.

- Planned Work for Subsequent Months. None. This effort has been transferred to the Organic Safety Program, and no additional develoment work will be conducted for the Ferrocyanide Safety Program.

- Milestone Status.

- September 30, 1995. Complete installation and deployment of the first phase of the neutron moisture monitoring system, and initiate monitoring. A letter report was issued September 27, 1995 (Lipke 1995b) that provides a summary and description of the design, construction, testing, calibration, and field deployment of the dual neutron probe system.

Electromagnetic Induction Probe. The purpose of this task is to deploy the EMI probe in the LOWs and possibly near the waste surface to measure moisture concentration. EMI probes operate by creating a magnetic field that induces current in a conductive medium. This induced current can be measured and is related to the media conductivity. The higher the electrical conductivity, the higher the free moisture content in the tank waste. 
The EMI probe is designed with four separate coils of wire that can be either exciting coils or sensing coils. The present configuration uses one coil as the exciting coil and three coils as the sensing coils. This configuration allows three different depths of penetration during one scan. The electronics can be programmed to use four frequencies during one scan, so the information acquired will be four frequencies at three different coil spacings. This information will be useful in separating the environment near the LOW from the environment far from the LOW. Two different EMI probes have been built, with different coil spacing and turns per coil, to determine in-tank responses.

Two areas of engineering activity apply to measurement of free moisture in the high-level waste tanks: (1) EMI measurement of absolute conductivity of the waste medium; and (2) determination of the electrical conductivity as a function of free moisture content of ferrocyanide or organic waste. Measurement of absolute conductivity is being studied using finite-element modeling of the EMI probe geometry. The modeling is being performed by Washington State University (WSU) using ET Analysis ${ }^{1}$, a proprietary code, and in-house using EMIP, an electromagnetic induction program developed at Oak Ridge National Laboratory during the early 1970 's.

- Progress During Reporting Period. Finite-element EMI probe simulations were completed this quarter at WSU, and the results were used to choose two different EMI probes for construction. EMI hardware, with necessary custom modifications and electrical adapters, were procured. Two EMI spiders to deploy the EMI probes into the LOWs were constructed for use with the draw-works for scanning the LOW between the bottom and top. Four electrical conductivity calibration standards were designed, constructed and delivered by Pacific Northwest Laboratory (PNL). Two EMI functionality standards for use in the field were designed, constructed and delivered by PNL.

The EMI probes were deployed in 241-BY-104, -BY-106, -BY-107, -BY-111, -BY-112, -TY-103, -TX-118, -TX-114 (3 LOWs), -S-105, and -S-106. There were tank scans using the 6-inch EMI probe with coil spacings of 1.5 inches, 3 inches and 6 inches, and several scans using the 12-inch EMI coil with coil spacings of 3 inches, 6 inches and 12 inches for comparison. The depth of penetration is roughly proportional to this coil spacing, although the EMI signal goes out beyond the coil spacing distance. The 6-inch coil, with fewer turns per coil, was used at frequencies between $50 \mathrm{kHz}$ and $500 \mathrm{kHz}$, and between $500 \mathrm{kHz}$ and $1.5 \mathrm{MHz}$. The 12-inch coil, with more turns per coil, was only used at frequencies between $50 \mathrm{kHz}$ and $500 \mathrm{kHz}$. Laboratory EMI measurements were made with the identical coil/frequency and amplification gain settings for the purpose of converting HLW tank scans into effective conductivity measurements.

\footnotetext{
${ }^{1}$ Trademark of Zetech, Inc., Issaquah, Washington.
} 
Observations of the in-tank acquired data allowed some conclusions about EMI to be made: (1) the system is sensitive to loss of hydraulic conductivity, which occurs about 0.08 to 0.12 volume fraction of liquid, depending on porosity; (2) the scan can interrogate multiple depths simultaneously; (3) EMI is sensitive to small changes in material properties; (4) EMI method measures conductivity directly, while moisture interpretation requires some assumptions; (5) EMI results are affected by temperature, so compensation is required; and (6) EMI method is strongly affected by ferromagnetic items.

A report was issued this quarter summarizing FY 1995 program activities on the EMI probe and describing the results of actual in-tank measurements. The report, WHC-SD-WM-ER-520, Rev. 0 (Crowe and Wittekind 1995), completes the September 30, 1995 milestone for this activity.

- Planned Work for Subsequent Months. None. This effort has been transferred to the Organic Safety Program, and no additional development work will be conducted for the Ferrocyanide Safety Program.

- Problem Areas and Action Taken. None.

- Milestone Status.

- May 30, 1995. Westinghouse Hanford Company acquires an EMI system compatible with surveillance van application. This milestone was completed on April 7, 1995. Procurement of a surveillance van specifically for EMI was not approved; consequently, acquisition of the EMI system fulfills this milestone.

- September 30, 1995. Westinghouse Hanford Company issues a report, cleared for public release, describing the FY 1995 engineering testing of the EMI moisture monitoring system. Report WHC-SD-WM-ER-520, Rev. 0 (Crowe and Wittekind 1995) was issued to complete this milestone.

\subsubsection{Moisture Retention Properties of Ferrocyanide Sludge and Saltcake Simulants}

The moisture content of ferrocyanide sludge is critical in preventing exothermic ferrocyanide/nitrate-nitrite reactions. Studies are underway to evaluate the moisture retention properties of ferrocyanide tank sludge and saltcake simulants as they relate to possible waste tank leaks, tank stabilization by pumping, and possible evaporation from exposed surfaces. Previous work (Epstein et al. 1994) has shown that ferrocyanide sludge cannot dry sufficiently to be chemically reactive during interim storage, either globally or locally. Dryout mechanisms evaluated included global evaporation, removal of liquid by leakage or pumping, boiling as a result of hot spots, and enhanced surface evaporation from hot spots. Current work is focusing on moisture retention in saltcake material, especially after a tank has been interim stabilized. 
Modeling calculations are being performed to estimate the moisture-retaining capability of ferrocyanide waste in typical Hanford Site tank systems. The effort focuses on evaluating the impact of consolidation and surface evaporation processes. Computer models are employed to estimate the moisture retention within the matrix and to determine surface drying of sludge and saltcake waste. To accomplish these objectives, the hydraulic properties of actual sludges and saltcake porous media must be compared with tested waste simulants, and their physical properties must be correlated.

Modeling work is being performed to examine the resistance of saltcake waste to gravity drainage and surface evaporation. Under gravity's influence, saturated saltcake will drain when liquid is pumped out and when a tank is stabilized. In contrast, sludge does not readily drain and the interstitial liquid must be expelled by consolidation, usually caused by an overburden. Because saltcake drains when stabilized, it is more subject to potential drying at the surface as a result of moisture evaporation.

- Progress During Reporting Period. Modeling of the moisture retention properties of saltcake and sludge waste was completed this quarter and a document issued (Simmons 1995). This report completes the moisture retention modeling for the Ferrocyanide Safety Program. However, additional saltcake modeling will be conducted next quarter for the Organic Safety Program.

Moisture retention modeling has shown that consolidation processes control water retention in sludge, and capillary forces control water retention in porous saltcake. Sludge decreases in water content when it is compressed by its own weight or by a drained overburden of saltcake. Saltcake retains water in interstices by capillary action and drains under the pull of gravity when a tank is stabilized. Tanks with more than a few feet of saltcake waste can dry out at the surface.

The In Farm 1 ferrocyanide simulant drainage test was completed this quarter. The water content of drained In Farm 1 simulant was determined as a function of location in the drainage column by sampling and analysis. Results show that for the 4-in.-diameter by 8-in.-high column (after consolidation the column height was 6 in.), the moisture varied consistently along five evenly-spaced locations from 46.1 weight percent (wt\%) water at the top to $47.8 \mathrm{wt} \%$ water at the bottom. The water content was measured along the center axis, and is in good agreement with the measured liquid that drained from the column during the three-year test period. The water content at the outer diameter of the column varied consistently along three evenly spaced locations from $47.4 \mathrm{wt} \%$ water at the top to $48.3 \mathrm{wt} \%$ water at the bottom. There appeared to be a wall effect on the amount of water retained since the water content near the wall was a little higher than the water content at the centerline. These results show that the ferrocyanide simulant strongly retains moisture even when there is an open path for moisture to drain.

- Planned Work for Subsequent Months. None. 
- Problem Areas and Actions Taken. None.

- Milestone Status.

- September 29, 1995. Pacific Northwest Laboratory issues a report, cleared for public release, on FY 1995 work on waste moisture modeling activities. This report was completed and issued on schedule (Simmons 1995).

\subsection{CHEMICAL REACTION STUDIES}

"The schedule for the program on study of the chemical properties and explosive behavior of the waste in these tanks is indefinite and does not reflect the urgent need for a comprehensive and definitive assessment of the probability of a violent chemical reaction. The study should be extended to other metallic compounds of ferrocyanide that are known or believed to be present in the tanks, so that conclusions can be generalized as to the range of temperature and other properties needed for a rapid chemical reaction with sodium nitrate."

Chemical reaction studies on ferrocyanide waste simulants are being conducted by Westinghouse Hanford Company, Fauske and Associates, Inc. (FAI), PNL, and Los Alamos National Laboratory (LANL). Westinghouse Hanford Company and PNL have produced flowsheet simulant materials for testing and characterization. FAI is conducting adiabatic calorimetry and propagation tests on these same flowsheet materials and on stoichiometric mixtures of pure sodium nickel ferrocyanide and sodium nitrate/nitrite. The test program at LANL was completed in FY 1993.

\subsubsection{Chemical Reaction Studies at Pacific Northwest Laboratory}

Chemical reaction studies are continuing at PNL using flowsheet simulant materials. Waste studies addressing DNFSB Recommendation 90-7.5 are being conducted to determine the following: (1) the aging effects (hydrolysis and radiolysis) from more than 35 years of storage in the tanks; (2) the correlation of waste simulant and actual waste properties; and (3) modeling calculations to predict the moisture-retaining capability of ferrocyanide waste in a typical tank system (this work is reported in Section 3.4.3).

- Progress During Reporting Period.

Aging Studies. A report on ferrocyanide degradation through hydrolysis and radiolysis was completed and released this quarter (Lilga et al. 1995). The work summarizes the results of aging experiments performed for the Ferrocyanide Safety Program. 
The influence of metal ions present in tank waste on In Farm simulant was investigated this quarter. Metal ions chosen for addition were bismuth, lead, zinc, and chromium because samples from tanks 241-C-112 and -C-109 showed that these ions were present in more than trace level concentrations. Figure 3-1 shows the results of the 13-day hydrolysis experiments with and without added metal ions, along with FY 1994 data that were collected under identical conditions in the same vessels. Lead, chromium, bismuth, and zinc ions do not affect the extent of aging of the ferrocyanide flowsheet simulant, as indicated by the amount of ammonia produced. Results of experiments containing these ions were statistically the same as results from identical control experiments that did not contain additives.

Comparison of Simulants and Actual Ferrocyanide Waste. The elemental concentrations of simulant and actual waste have been measured using inductively coupled argon plasma atomic emission spectroscopy. Results from these analyses were reported in the previous quarterly report (Meacham et al. 1995b). A report comparing the analytical results was released this quarter (Scheele 1995).

- Planned Work For Subsequent Months. Aging experiments will continue into the first two quarters of next FY 1996 using the In Farm flowsheet simulant. Aging experiments will be completed by March 1996.

- Problem Areas and Actions Taken. Some aging experiments (conducted at low pH and low temperature) were not completed this fiscal year; therefore, experiments will be continued until March 1996. The final report on aging experiments will be revised to include these results by June $28,1996$.

- Milestone Status.

- September 29, 1995. PNL issues the final report integrating all Ferrocyanide Safety Program hydrolysis and radiolysis aging activities.

- September 29, 1995. PNL issues the final report, available to the public, on studies comparing chemical and physical parameters of ferrocyanide waste simulants with actual tank waste samples.

- June 28, 1996. PNL revises aging report to include the results of experiments carried over into FY 1996. 
Figure 3-1. Influence of Added Metal Ions on Hydrolysis of In Farm Simulant at $90{ }^{\circ} \mathrm{C}$ With an Applied Gamma Dose Rate of $1.07 \times 10^{5} \mathrm{Rad} / \mathrm{h}$.

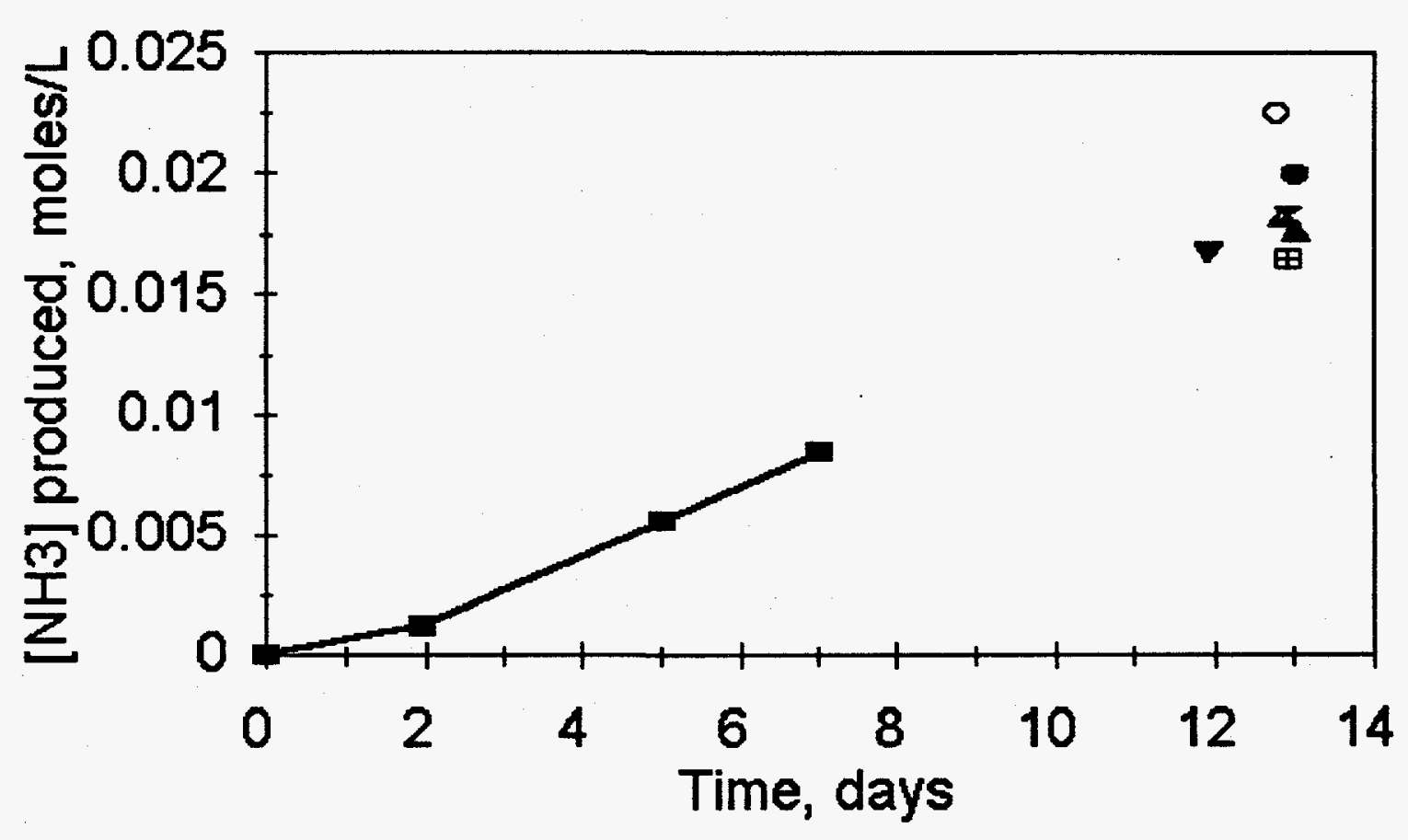

\begin{tabular}{|c|c|c|c|}
\hline $\begin{array}{l}-\mathrm{H} 1 \\
\nabla \mathrm{Pb} 2\end{array}$ & $\begin{array}{l}\text { - Zn1 control } \\
\wedge \mathrm{Pb} 3\end{array}$ & $\begin{array}{l}\text { Zn2 } \\
\text { I } \mathrm{Cr} 1\end{array}$ & $\begin{array}{l}\triangle \mathrm{Pb} 1 \text { control } \\
\text { 田 } \mathrm{Bi1}\end{array}$ \\
\hline
\end{tabular}




\subsubsection{Preparation and Characterization of Ferrocyanide Simulants}

Pure sodium nickel ferrocyanide is being prepared and analyzed to determine its chemical reaction properties with stoichiometric mixtures of sodium nitrate/nitrite as a function of water content. These tests are being conducted by FAI to clearly define the margin of safety between the theoretical and experimental propagation limits for ferrocyanide. These tests are run in the FAI reactive systems screening tool. These tests and previous tests with simulants-along with analyses of actual tank waste samples, waste tank monitoring, and waste modeling--provide information to characterize with a great deal of assurance safety concerns relating to the sludge in the ferrocyanide tanks.

- Progress During Reporting Period. Two batches, each about 300 grams, of triple-washed and dried single-phase $\mathrm{Na}_{2} \mathrm{NiFe}(\mathrm{CN})_{6}$ were prepared at Westinghouse Hanford Company. The two batches will be blended and analyzed for confirmatory analysis and a portion will be sent to FAI to provide material for additional propagation tests as part of the Organic Safety Program. Some of this material will be sent to various other laboratories for analytical technique evaluations (such as FTIR and Raman spectroscopy) sponsored by other programs.

Heats of reaction were measured on the sludge material in the completed $11.1-\mathrm{cm}$ (4-in.)-diameter In Farm 1 drainage column test (see Section 3.4.3). The In Farm 1 simulant showed very little difference in the measured heats of reaction for material taken along the centerline from the top of the column to the bottom. The values varied from 718 joules per gram $(\mathrm{J} / \mathrm{g}$ ) of dry material at the top to $662 \mathrm{~J} / \mathrm{g}$ dry simulant at the middle. These results imply that there is little or no migration of ferrocyanide in the sludge over time.

A report on the contact ignition criteria (CTI) for propagating reactions was released this quarter (Fauske et al. 1995a). The CTI report describes the theory and experiments used to develop safety criteria for ferrocyanide and organic waste. From the CTI theory, the minimum requirement to support a propagating reaction is a chemical energy release greater than $1,200 \mathrm{~J} / \mathrm{g}\left[\sim 10 \mathrm{wt} \% \mathrm{Na}_{2} \mathrm{NiFe}(\mathrm{CN})_{6}\right]$ in dry waste. The amount of water required to prevent propagation varies linearly as a function of fuel concentration until $20 \mathrm{wt} \%$. For water concentrations greater than $20 \mathrm{wt} \%$, no amount of fuel and oxidizer will support a propagating reaction.

A final report on chemical reactivity testing of simulants was completed this quarter (Fauske et al. 1995b). The report summarizes the results of propagation testing on ferrocyanide waste simulants at FAI. All the ferrocyanide waste simulant experiments have been completed and no additional chemical reactivity testing of simulants is planned.

- Planned Work for Subsequent Months. None. 
- Problem Areas and Actions Taken. None.

- Milestone Status.

- July 31, 1995. Westinghouse Hanford Company releases a report, approved for public release, documenting the development and confirmation by testing of the contact temperature ignition criterion model. This milestone was completed this quarter (Fauske et al. 1995a).

- September 30, 1995. Westinghouse Hanford Company completes the ferrocyanide calorimetry and propagation test program at FAI as specified by Westinghouse Hanford Company, and prepares a report, available for public release, that supports final resolution of the Ferrocyanide Safety Issue. The report was completed and released on schedule (Fauske et al. 1995b).

- September 30, 1996. Complete FAI support for Ferrocyanide Safety Issue resolution and conclude chemical reactivity studies of chemical waste. This will close DNFSB Recommendation 90-7.5.

\subsection{EMERGENCY RESPONSE PLANNING}

"The Board had recommended 'that an action plan be developed for the measures to be taken to neutralize the conditions that may be signaled by alarms.' Two types of measures are implied: actions to respond to unexpected degradation of a tank or its contents, and actions to be taken if an explosion were to occur. Your implementation plan stated that 'the current contingency plans ... will be reviewed and revised if needed.' We do not consider that this proposed implementation of the Board's recommendation is adequately responsive. It is recommended that a written action plan founded on demonstrated principles be prepared as soon as possible, that would respond to indications of onset of abnormal temperatures or other unusual conditions in a ferrocyanide-bearing tank, to counter any perceived growth in hazard. A separate emergency plan should be formulated and instituted, covering measures that would be taken in event of an explosion or other event leading to an airborne release of radioactive material from the tanks, and that would protect personnel both on and off the Hanford Site. The Board believes that even though it is considered that the probability is small that such an event will occur, prudence dictates that steps be taken at this time to prepare the means to mitigate the unacceptable results that could ensue."

The original Action Plan for Response to Abnormal Conditions in Hanford Radioactive Waste Tanks Containing Ferrocyanide (Cash and Thurman 1991) was prepared in response to DNFSB Recommendation 90-7.6. The plan describes the steps to be taken if a temperature increase trend above the tank temperature baseline is measured in any of the ferrocyanide tanks. The document was revised (Cash and Thurman 1992) to include the monitoring 
criteria and responses for abnormal levels of flammable and toxic gases, as well as the reporting requirements, if established criteria are exceeded. The second revision of the plan was released in June 1994 (Fowler 1994).

The Tank Farm Stabilization Plan For Emergency Response (WHC 1991) was issued in March 1991. If a radioactive release from a ferrocyanide tank were to occur, it would be detected by one or more radiation monitoring systems. Significant airborne or ground surface releases that spread beyond the immediate tank or tank farm would be detected by the tank farm area radiation detectors. These monitoring systems are on all tank farms. An emergency involving an underground radioactive waste storage tank is a unique event with potentially serious consequences both onsite and offsite. The Stabilization Plan provides quick, preplanned actions that can be used to stabilize an emergency event at an underground radioactive waste storage tank.

All actions with respect to emergency planning, emergency event recognition, protective action recommendations, and emergency response procedures have been completed. Further revisions and occasional validation exercises will be accomplished as part of the normal Westinghouse Hanford Company and DOE emergency planning efforts. No further reporting on these issues is planned, and this part of DNFSB Recommendation 90-7.6 is considered complete and closed.

DOE considers this recommendation to be closed with the provisos that the abnormal conditions response plan and emergency plans are reviewed on a periodic basis and revised and updated as required to incorporate any additional controls determined appropriate by the ongoing Waste Tank Safety Program investigations (e.g., the Action Plan for Response to Abnormal Conditions in Hanford Site Radioactive Waste Tanks Containing Ferrocyanide was updated and released in June 1994 [Fowler 1994]); and that validation exercises for various waste tank accident scenarios are conducted periodically (exercises for the tank farms are conducted every two years).

- Progress During Reporting Period. As noted in previous reports, all of the planned milestones for this task were completed.

- Planned Work For Subsequent Months. None planned.

- Problem Areas and Action Taken. None.

- Milestone Status. All milestones have been completed. 


\subsection{IMPLEMENTATION OF THE WYDEN AMENDMENT}

The Wyden Amendment (Public Law 101-510, Section 3137 [1990]) requires that:

"...the Secretary of Energy shall identify which single-shelled or double-shelled high-level nuclear waste tanks at the Hanford Nuclear Reservation, Richland, Washington, may have a serious potential for release of high-level waste due to uncontrolled increases of temperature or pressure. After completing such identification, the Secretary shall determine whether continuous monitoring is being carried out to detect a release or excessive temperature or pressure at each tank so identified. If such monitoring is not being carried out, as soon as practicable the Secretary shall install such monitoring, but only if a type of monitoring that does not itself increase the danger of a release can be installed."

\subsection{THE WATCH LIST}

In March 1989, using process knowledge, process records, transfer records, and log books, Westinghouse Hanford Company (Nguyen 1989) identified 22 Hanford Site tanks as potentially containing $1,000 \mathrm{~g}$-moles $(211 \mathrm{~kg}$ [465 lb]) or more of ferrocyanide [as the $\mathrm{Fe}(\mathrm{CN})_{6}^{4}$ anion]. To avert possible injury to personnel and damage to the facility or environment, strict controls were identified for these and other tanks with safety issues. These controls were described in the document, Operating Specifications for Watch List Tanks (WHC 1990). Tanks identified by this document (see WHC [1995] for latest revision) have been commonly referred to as Watch List tanks. Two additional ferrocyanide tanks were identified in January 1991 (Borsheim and Cash 1991), increasing the total number of ferrocyanide tanks to 24 .

In November 1990, the Wyden Amendment (Public Law 101-510, Section 3137 [1990]) was enacted. This law required the identification of Hanford Site tanks that may have a serious potential for release of high-level waste. In February 1991 (Harmon 1991), the 24 ferrocyanide tanks were among the tanks identified, and were included in the subsequent July 1991 report to Congress (Watkins 1991) that responded to the Wyden Amendment. However, re-examination of the historical records (Borsheim and Simpson 1991) indicated that six of the 24 tanks did not contain the requisite $1,000 \mathrm{~g}$-moles of ferrocyanide. Therefore, these six tanks should not have been included on the Watch List nor been identified in the response to the Wyden Amendment. The six tanks were subsequently removed from the Watch List (Anttonen 1993, Sheridan 1994b) (Note: these tanks do not contain greater than $8 \mathrm{wt} \% \mathrm{Na}_{2} \mathrm{NiFe}(\mathrm{CN})_{6}$ and should not be on the Watch List for this reason also).

As part of the overall safety screening module being conducted by Westinghouse Hanford Company Tank Waste Remediation System, all of the Hanford Site SSTs will be core sampled and characterized. Eighteen ferrocyanide tanks are currently on the Watch List, and no more ferrocyanide tanks are expected to be added to the Watch List. 
Work conducted since 1991 on ferrocyanide reactions has resulted in a change of the criterion used for placing ferrocyanide tanks on the Watch List. The 1,000 g-mole inventory criterion has now been replaced with a fuel concentration criterion of 115 calories per gram (cal/g) of dry sample (this is an energy equivalent to a concentration of $8 \mathrm{wt} \% \mathrm{Na}_{2} \mathrm{NiFe}(\mathrm{CN})_{6}$ in the waste). This fuel concentration criterion more accurately reflects the risk associated with ferrocyanide tanks. Ferrocyanide tanks with concentrations less than an energy equivalent of $8 \mathrm{wt} \% \mathrm{Na}_{2} \mathrm{NiFe}(\mathrm{CN})_{6}$ cannot support a propagating reaction, and are categorized as safe. Detailed rationale for the $115 \mathrm{cal} / \mathrm{g}$ of dry fuel concentration criterion is presented in Postma et al. (1994a).

Core sampling and characterization efforts will determine the ferrocyanide concentration for those tanks that bound aging (see Sections 2.2 and 3.4). After adequate characterization, if these tanks contain concentrations less than $8 \mathrm{wt} \% \mathrm{Na}_{2} \mathrm{NiFe}(\mathrm{CN})_{6}$ (i.e., the fuel value of the maximum concentration is less than $115 \mathrm{cal} / \mathrm{g}$ ), then a request will be made by Westinghouse Hanford Company for DOE concurrence to remove all the ferrocyanide tanks from the Watch List.

Some sample bias and analytical error are unavoidable; therefore, confidence intervals have been established to specify when it is appropriate to conclude that a ferrocyanide tank contains concentrations less than an energy equivalent of $8 \mathrm{wt} \% \mathrm{Na}_{2} \mathrm{NiFe}(\mathrm{CN})_{6}$. An $80 \%$ confidence interval was chosen for tanks with a fuel concentration of $8 \mathrm{wt} \%$ $\mathrm{Na}_{2} \mathrm{NiFe}(\mathrm{CN})_{6}$. That is, if five ferrocyanide tanks contain exactly an energy equivalent of $8 \mathrm{wt} \% \mathrm{Na}_{2} \mathrm{NiFe}(\mathrm{CN})_{6}$, statistically, four tanks would remain on the Watch List and one tank would be removed. The possibility of removing a ferrocyanide tank from the Watch List decreases substantially as the fuel concentration increases. The confidence intervals increase to $95 \%$ and $99 \%$ at $\mathrm{Na}_{2} \mathrm{NiFe}\left(\mathrm{CN}_{6}\right.$ concentrations of $12 \%$ and $15 \mathrm{wt} \%$, respectively. Detailed discussions on how sample bias and analytical error are factored into determining the actual fuel concentrations in a ferrocyanide tank are given in the Ferrocyanide Data Quality Objectives document (Meacham et al. 1994).

- Planned Work To Complete Program. An increased understanding of ferrocyanide aging indicates that little ferrocyanide remains, and the assumption that it is necessary to core sample all ferrocyanide tanks may not be valid. By characterizing the waste in only those tanks that bound aging (i.e., tanks with conditions least conducive to aging), the Ferrocyanide Safety Issue could be resolved much earlier and at a substantially reduced cost. As more core sample data become available, the need to sample all the ferrocyanide tanks will be reexamined.

\section{- Milestones.}

- January 31, 1996. Westinghouse Hanford Company issues documentation supporting resolution of the Ferrocyanide Safety Issue for the four C Farm tanks, and recommends resolution of the Ferrocyanide Safety Issue for C Farm tanks. All four C Farm tanks have been sampled and data interpretation reports have been completed for the tanks. 
- July 31, 1996. Westinghouse Hanford Company receives DOE approval to resolve the Ferrocyanide Safety Issue for C Farm tanks.

- March 31, 1997. Westinghouse Hanford Company prepares documentation to support resolution of the Ferrocyanide Safety Issue for the last 14 ferrocyanide tanks, and recommends Ferrocyanide Safety Issue resolution.

- September 30, 1997. Westinghouse Hanford Company receives DOE approval to resolve the Ferrocyanide Safety Issue. This completes the Ferrocyanide Safety Program.

\subsection{TEMPERATURE MONITORING}

The installation of temperature monitoring capabilities is discussed in Sections 3.1.2.1 and 3.2.2. Installation of instrument trees and continuous temperature monitoring are considered prudent waste management practices. Therefore, new instrument trees will be installed in ferrocyanide tanks, even though the ferrocyanide waste has aged and little fuel value remains. Instrument trees have been installed in all ferrocyanide tanks and are continuously monitored by TMACS (see Section 3.1.2.1 for discussion on instrument trees).

- Planned Work To Complete Program. None.

- Milestones.

- September 30, 1995. Westinghouse Hanford Company completes installation of instrument trees in all ferrocyanide tanks and connects trees to TMACS. This milestone was completed this quarter.

\subsection{PRESSURE MONITORING}

The ferrocyanide tanks were initially identified as having "a serious potential for release" and were placed on the Watch List because insufficient data were available on the probability for ferrocyanide-nitrate/nitrite reactions. Pressure monitoring instrumentation is not presently installed on the ferrocyanide tanks. It would take several years to install pressure monitoring instrumentation because of the capital project time cycle. Ferrocyanide waste has probably degraded (aged) significantly, and all of the tanks may now contain less than the $8 \mathrm{wt} \%$ $\mathrm{Na}_{2} \mathrm{NiFe}(\mathrm{CN})_{6}$ fuel concentration specified for the safe category (see also Postma et al. 1994a). This eliminates the need for continuous pressure monitoring for offgases from a ferrocyanide reaction. 
The rationale for not installing pressure monitors in ferrocyanide tanks was prepared and submitted to DOE in July 1994 (Payne 1994b). Low gas generation rates (Fowler and Graves 1994) and the low potential for exothermic ferrocyanide reactions (Postma et al. 1994a) indicated that continuous pressure monitoring is not warranted.

- Planned Work For Subsequent Months. No additional work is planned in this area, because DOE has concurred that pressure monitoring is not required as stated in the revised Ferrocyanide Safety Issue Program Plan (O'Leary 1994).

- Milestones. None. 


\subsection{PROGRAM SCHEDULES AND MILESTONES}

Schedules (Figure 5-1) are presented in this section. The schedules review milestones for FY 1994 through the expected end of the program in FY 1997. The sequence and anticipated completion dates of the major milestones leading to resolution of the Ferrocyanide Safety Issue are presented. Closure of DNFSB recommendations are indicated on the schedule as diamonds, and completion of interim milestones are indicated as triangles. The schedules are statused through September 30, 1995. 
Figure 5-1. Ferrocyanide Waste Tank Safety Schedule. (Sheet 1 of 2)

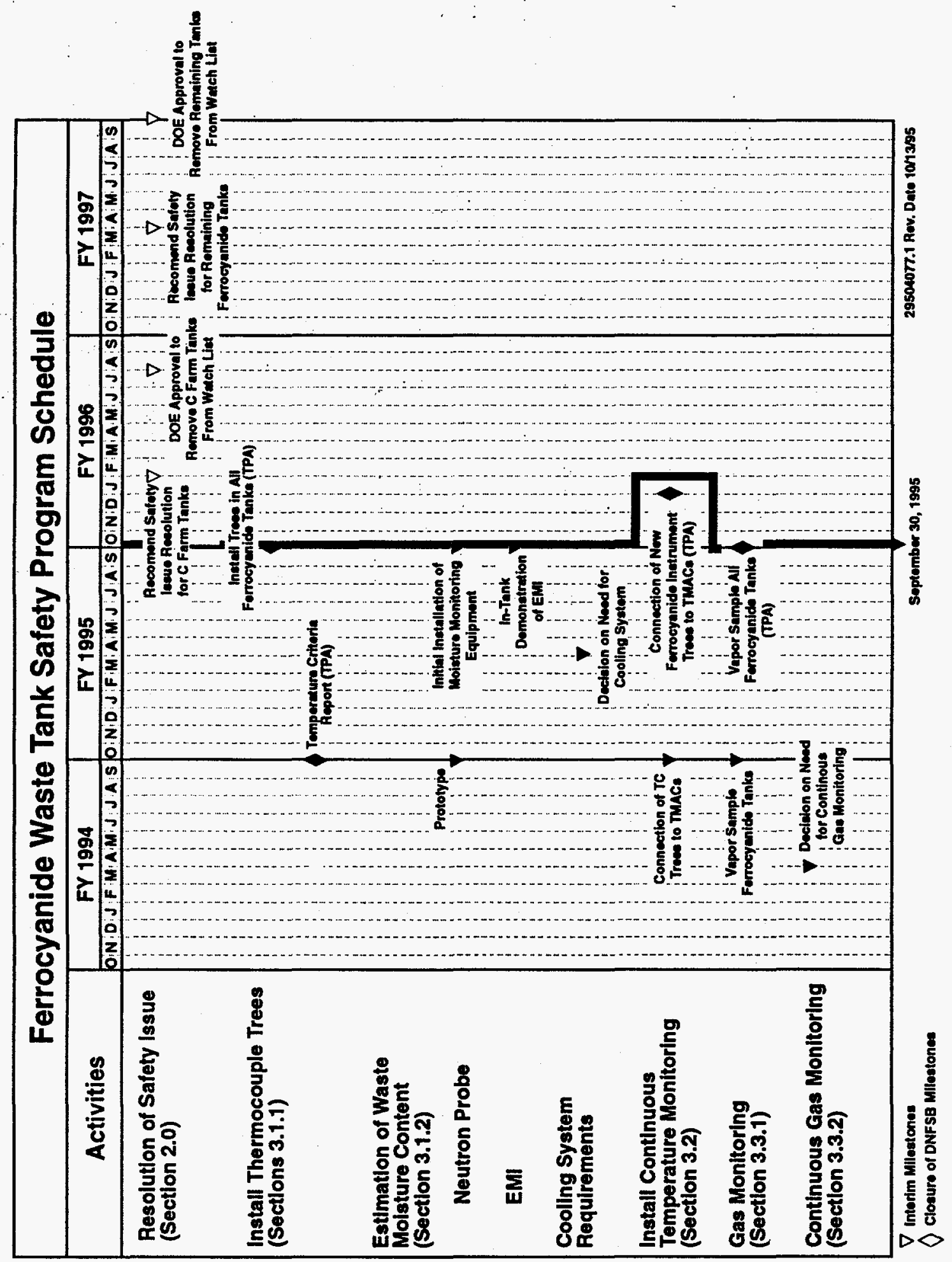


Figure 5-1. Ferrocyanide Waste Tank Safety Schedule. (Sheet 2 of 2)

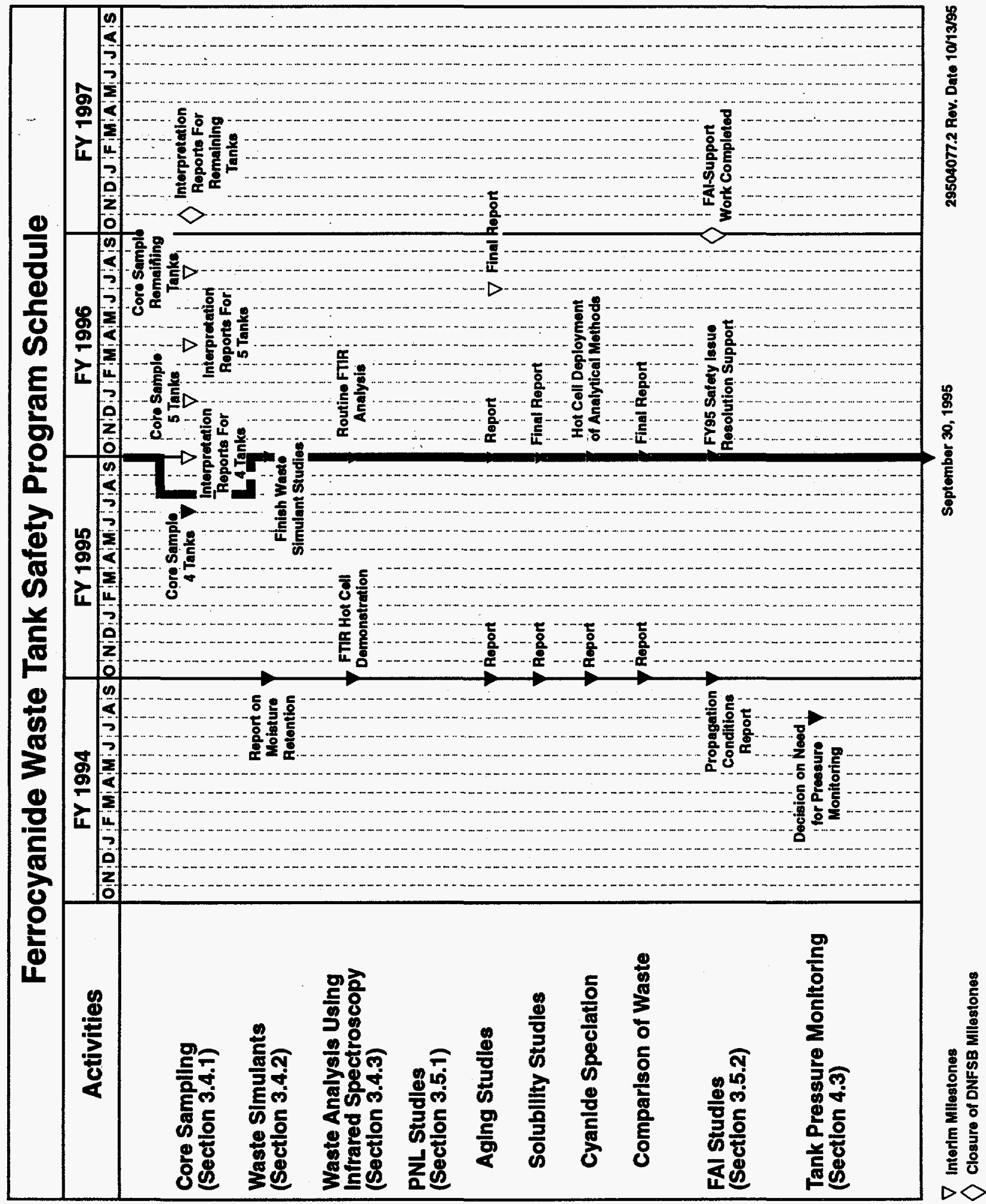


WHC-EP-0474-18

This page intentionally left blank. 


\subsection{REFERENCES}

Anttonen, J. H., 1993, Resolution of Unreviewed Safety Question (USQ) for Four Ferrocyanide Tanks, (letter 9304645B/93-CAB-223 to T. M. Anderson, President, Westinghouse Hanford Company, July 9), U.S. Department of Energy, Richland Operations Office, Richland, Washington.

Borsheim, G. L., and R. J. Cash, 1991, Unusual Occurrence - Addition of Two Tanks to List of Unreviewed Safety Question Tanks Containing Ferrocyanide, WHC-91-0096-TFARM, February 13, Westinghouse Hanford Company, Richland, Washington.

Borsheim, G. L., and B. C. Simpson, 1991, An Assessment of the Inventories of Ferrocyanide Watch List Tanks, WHC-SD-WM-EP-133, Rev. 0, Westinghouse Hanford Company, Richland, Washington.

Bussell, J. H., 1992, Engineering Evaluation of Thermocouples in Ferrocyanide Watch List Tanks, WHC-SD-WM-ER-134, Rev. 0 and Rev. 0A, Westinghouse Hanford Company, Richland, Washington.

Cady, H. H., 1993, Evaluation of Ferrocyanide/Nitrate Explosive Hazard, LA-12589-MS, Los Alamos National Laboratory, Los Alamos, New Mexico.

Callaway, W.S., 1995, Scanning Electron Microscopic Analyses of Ferrocyanide Tank Wastes for the Ferrocyanide Safety Program - FY 1995 Report, WHC-SD-WM-RPT-194, Rev. 0, Westinghouse Hanford Company, Richland, Washington.

Cash, R. J., 1991, Implementation Plan for the Defense Nuclear Facilities Safety Board Recommendation 90-7, WHC-EP-0415, Rev. 0, Westinghouse Hanford Company, Richland, Washington.

Cash, R. J., and J. M. Thurman, 1991, Action Plan for Response to Abnormal Conditions in Hanford Site Radioactive Waste Tanks Containing Ferrocyanide, EP-0407, Rev. 0, Westinghouse Hanford Company, Richland, Washington.

Cash, R. J., and J. M. Thurman, 1992, Action Plan for Response to Abnormal Conditions in Hanford Site Radioactive Waste Tanks Containing Ferrocyanide, EP-0407, Rev. 1, Westinghouse Hanford Company, Richland, Washington.

Claybrook, S. W., and S. A. Wood, 1994, Organic Evaporation in Waste Tank C-103, WHC-SD-WM-ER-344, Rev. 0, Westinghouse Hanford Company, Richland, Washington.

Crowe, R. D., M. Kummerer, and A. K. Postma, 1993, Estimation of Heat Load in Waste Tanks Using Average Vapor Space Temperatures, WHC-EP-0709, Rev. 0, Westinghouse Hanford Company, Richland, Washington. 
Crowe, R. D. and W. D. Wittekind, 1995, Ferrocyanide Safety Program: In-Tank Application of Electromagnetic Induction (EMI) Moisture Measurements - FY 1995 Report, WHC-SD-WM-ER-520, Rev. 0, Westinghouse Hanford Company, Richland, Washington.

Deaton, D. E., 1990, Unusual Occurrence - Unreviewed Safety Questions Regarding Tanks Containing Ferrocyanide, WHC-90-B003-R1 (Update 10-22-90), Westinghouse Hanford Company, Richland, Washington.

Dickinson, D. R., J. M. McLaren, G. L. Borsheim, and M. D. Crippen, 1993, Ferrocyanide Safety Program: Credibility of Drying Out Ferrocyanide Tank Waste by Hot Spots, WHC-EP-0648, Rev. 0, Westinghouse Hanford Company, Richland, Washington.

DOE, 1987, Final Environmental Impact Statement, Disposal of Hanford Defense High-Level, Transuranic and Tank Waste, Hanford Site, Richland, Washington, DOE/EIS-0113, Vol. 1 through 5, U.S. Department of Energy, Washington, D.C.

DOE, 1994a, Recommendation 93-5 Implementation Plan, DOE/RL 94-0001, U.S. Department of Energy, Richland Operations Office, Richland, Washington.

DOE, 1994b, Program Plan for Resolution of the Ferrocyanide Waste Tank Safety Issue at the Hanford Site, DOE/RL-94-110, Rev. 1, U.S. Department of Energy, Richland Operations Office, Richland, Washington.

Ecology, EPA, and DOE, 1994, Hanford Federal Facility Agreement and Consent Order, as amended, Washington State Department of Ecology, U.S. Environmental Protection Agency, and U.S. Department of Energy, Olympia, Washington.

Epstein, M., H. K. Fauske, M. D. Crippen, D. R. Dickinson, J. D. McCormack, R. J. Cash, J. E. Meacham, and C. S. Simmons, 1994, Ferrocyanide Safety Program: An Assessment of the Possibility of Ferrocyanide Sludge Dryout, WHC-EP-0816, Rev. 0, Westinghouse Hanford Company, Richland, Washington.

Fauske, H. K., D. R. Dickinson, R. J. Cash, and J. E. Meacham, 1995a, The Contact Ignition (CTI) Criteria for Propagating Chemical Reactions Including the Effect of Moisture and Application to Hanford Waste, WHC-SD-WM-ER-496, Rev. 0, Westinghouse Hanford Company, Richland, Washington.

Fauske, H. K., R. J. Cash, and J. E. Meacham, 1995b, Ferrocyanide Safety Program: Final Report on Adiabatic Calorimetry and Tube Propagation Tests With Synthetic Ferrocyanide Materials, WHC-SD-WM-ER-519, Rev. 0, Westinghouse Hanford Company, Richland, Washington. 
Finfrock, S. H., 1995a, Project Management Plan for the TMAD Code, WHC-SD-WM-CSRS-027, Rev. 0, Westinghouse Hanford Company, Richland, Washington.

Finfrock, S. H., 1995b, System Design Description for the TMAD Code, WHC-SD-WM-CSRS-028, Rev. 0, Westinghouse Hanford Company, Richland, Washington.

Finfrock, S. H., 1995c, Validation and Verification Report for the TMAD Code, WHC-SD-WM-CSRS-029, Rev. 0, Westinghouse Hanford Company, Richland, Washington.

Finfrock, S. H., 1995d, User's Manual for the TMAD Code, WHC-SD-WM-CSRS-030, Rev. 0, Westinghouse Hanford Company, Richland, Washington.

FR, 1990, "Implementation Plan for Recommendation 90-3 at the Department of Energy's Hanford Site, Washington, "Federal Register, Defense Nuclear Facilities Safety Board Recommendation 90-7, Vol. 55, No. 202, pp. 42243 - 42244.

Fowler, K. D., 1994, Action Plan for Response to Abnormal Conditions in Hanford Site Radioactive Waste Tanks Containing Ferrocyanide, WHC-EP-0407, Rev. 2, Westinghouse Hanford Company, Richland, Washington.

Fowler, K. D., and R. D. Graves, 1994, Decision Analysis for Continuous Cover Gas Monitoring of Ferrocyanide Watch List Tanks, WHC-EP-0743, Rev. 0, Westinghouse Hanford Company, Richland, Washington.

Gerton, R. E., 1994, Environmental Assessment (EA) and Finding of No Significant Impact (FONSI) for the Waste Tank Safety Program at the Hanford Site, (DOE/EA-0915), (letter 9402034B/94-SST-053 to President, Westinghouse Hanford Company, March 8), U.S. Department of Energy, Richland, Washington.

Grigsby, J. M., D. B. Bechtold, G. L. Borsheim, M. D. Crippen, D. R. Dickinson, G. L. Fox, D. W. Jeppson, M. Kummerer, J. M. McLaren, J. D. McCormack, A. Padilla, B. C. Simpson, and D. D. Stepnewski, 1992, Ferrocyanide Waste Tank Hazard Assessment-Interim Report, WHC-SD-WM-RPT-032, Rev. 1, Westinghouse Hanford Company, Richland, Washington.

Harmon, H. D., 1991, Safety Measures for Waste Tanks at Hanford Site, Richland, Washington, (letter 9059124.1 to R. E. Gerton, DOE-RL, February 8), Westinghouse Hanford Company, Richland, Washington.

Kelly, S. E., 1995a, Tank Characterization Report for Single Shell Tank 241-C-111, WHC-SD-WM-ER-475, Rev. 0-B, Westinghouse Hanford Company, Richland, Washington. 
Kelly, S. E., 1995b, Tank Characterization Report for Single Shell Tank 241-TY-104, WHC-SD-WM-ER-481, Rev. 0-A, Westinghouse Hanford Company, Richland, Washington.

Kress, T., K. Bandyopadhyay, P. d'Entremont, S. Slezak, and M. Reich, 1990, Risk of a Ferrocyanide Explosion in the Hanford Waste Tank Farm, (memorandum to John Tseng, DOE-HQ, September 20), Ad Hoc Task Force formed by U.S. Department of Energy to evaluate the ferrocyanide safety concerns at the Hanford Site, Oak Ridge National Laboratory, Oak Ridge, Tennessee.

Lilga, M. A., E. V. Anderson, R. T. Hallen, M. O. Hogan, T. L. Hubler, G. L. Jones, D. J. Kowalski, M. R. Lumetta, G. F. Schiefelbein, and M. R. Telander, 1995, Ferrocyanide Safety Project Ferrocyanide Againg Studies FY 1995 Annual Report, PNL-10713, Pacific Northwest Laboratory, Richland, Washington.

Lipke, E. J., 1995a, Ferrocyanide Safety Program: Completion of Milestone Report on Tank Moisture Data Interpretation Computer Program, (letter 9554603 to R. E. Gerton, DOE-RL, August 30), Westinghouse Hanford Company, Richland, Washington.

Lipke, E. J. 1995b, Ferrocyanide Safety Program: Completion of Milestone T2B-95-118 on Measurement of Tank Moisture in Ferrocyanide Tanks, (letter 9555202 to M. F. Jarvis, DOE-RL, September 27), Westinghouse Hanford Company, Richland, Washington.

McLaren, J. M., 1993, Ferrocyanide Safety Program: Updated Thermal Analysis Model for Ferrocyanide Tanks with Application to Tank 241-BY-104, WHC-EP-0669, Rev. 0, Westinghouse Hanford Company, Richland Washington.

McLaren, J. M., 1994a, Ferrocyanide Safety Program: Thermal Analysis of Ferrocyanide Tanks, Group I, WHC-EP-0729, Rev. 0, Westinghouse Hanford Company, Richland, Washington.

McLaren, J. M. 1994b, Ferrocyanide Safety Program: Thermal Analysis of Ferrocyanide Watch List Tanks, Group II, WHC-EP-0794, Rev. 0, Westinghouse Hanford Company, Richland, Washington.

Meacham, J. E., H. Babad, and H. Toffer, 1993, Moisture Monitoring of Ferrocyanide Tanks: An Evaluation of Methods and Tools, WHC-EP-0658, Rev. 0, Westinghouse Hanford Company, Richland, Washington.

Meacham, J. E., R. J. Cash, B. A. Pulsipher, and G. Chen, 1995a, Data Requirements for the Ferrocyanide Safety Issue Developed Through the Data Quality Objectives Process, WHC-SD-WM-DQO-007, Rev. 1, Westinghouse Hanford Company, Richland, Washington. 
Meacham, J. E., R. J. Cash, and G. T. Dukelow, 1995b, Quarterly Report on the Ferrocyanide Safety Program for the Period Ending June 30, 1995, WHC-EP-0474-17, Westinghouse Hanford Company, Richland, Washington.

Nguyen, D. M., 1989, Data Analysis of Conditions in Single-Shell Tanks Suspected of Containing Ferrocyanide, (intemal memorandum 13314-89-025 to N. W. Kirch, March 2), Westinghouse Hanford Company, Richland, Washington.

O'Leary, H. R., 1994, /Transmittal of "Program Plan for Evaluation of the Ferrocyanide Waste Tank Safety issue at the Hanford Site, "DOE/RL-94-110], (letter to J. T. Conway, Chairman, Defense Nuclear Facilities Safety Board, December 2), U.S. Department of Energy, Washington, D.C.

Payne, M. A., 1994a, Ferrocyanide Safety Program: Transmittal of General Accounting Office Closeout Report, (letter 9454280 to R. E. Gerton, DOE-RL, June 16), Westinghouse Hanford Company, Richland, Washington.

Payne, M. A., 1994b, Ferrocyanide Safety Program: Continuous Pressure Monitoring in Ferrocyanide Watch List Tanks, (letter 9455175 to R. E. Gerton, DOE-RL, July 29), Westinghouse Hanford Company, Richland, Washington.

Peach, J. D., 1990, Consequences of Explosion of Hanford's Single-Shell Tanks are Understated, (letter B-241479 to M. Synar, Chairman, Environment, Energy, and Natural Resources Subcommittee, Committee on Government Operations, House of Representatives, October 10), GAO/RCED-91-34, U.S. General Accounting Office, Washington, D.C.

Postma, A. K., J. E. Meacham, G. S. Barney, G. L. Borsheim, R. J. Cash, M. D. Crippen, D. R. Dickinson, J. M. Grigsby, D. W. Jeppson, M. Kummerer, J. M. McLaren, C. S. Simmons, and B. C. Simpson, 1994a, Ferrocyanide Safety Program: Safety Criteria for Ferrocyanide Watch List Tanks, WHC-EP-0691, Westinghouse Hanford Company, Richland, Washington.

Postma, A. K., D. B. Bechtold, G. L. Borsheim, J. M. Grigsby, R. L. Guthrie, M. Kummerer, M. G. Plys, and D. A. Turner, 1994b, Safety Analysis of Exothermic Reaction Hazards Associated with the Organic Liquid Layer in Tank 241-C-103, WHC-SD-WM-SARR-001, Rev. 0, Westinghouse Hanford Company, Richland, Washington.

Parra, S. A., 1995, Test Results for Qualification of the Self-Installing Liquid Observation Well, WHC-SD-WM-TD-008, Westinghouse Hanford Company, Richland, Washington.

Public Law 101-510, Section 3137, 1990, Safety Measures for Waste Tanks at Hanford Nuclear Reservation, U.S. Congress, Washington, D.C. [Also referred to as the Wyden Amendment] 
Rai, D., A. R. Felmy, S. C. Smith, and J. L. Ryan, 1994, Ferrocyanide Safety Project: Interim Report FY 1994 - Solubility of Ferrocyanide Compounds, PNL-10150, Pacific Northwest Laboratory, Richland, Washington.

Rebagay, T. V., R. J. Cash, D. A. Dodd, C. T. Narquis, F. R. Reich, and W. D. Winkelman, 1995, Remote Characterization of Mixed Waste by Fourier Transform Infrared Spectroscopy, WHC-SD-WM-RPT-192, Rev. 0, Westinghouse Hanford Company, Richland, Washington.

Reich, F. R., R. E. Johnson, B. L. Philipp, J. B. Duncan, and G. L. Schutzenhofer, 1994, Summary of Fiscal Year 1994 Near-Infrared Spectroscopy Moisture Sensing Activities, WHC-EP-0839, Westinghouse Hanford Company, Richland, Washington.

Riedel, E. F., 1995, Ferrocyanide Safety Program: FY 1995 Report on Mössbauer Spectroscopy Task Activities, WHC-SD-WM-RPT-195, Rev. 0, Westinghouse Hanford Company, Richland, Washington.

Sasaki, L. M., 1995, Tank Characterization Report for Single Shell Tank 241-C-108, WHC-SD-WM-ER-503, Rev. 0, Westinghouse Hanford Company, Richland, Washington.

Scheele, R. D., 1995, Ferrocyanide Safety Project: Comparison of Actual and Simulated Ferrocyanide Waste Properties, PNL-10175, Supplement 1, Pacific Northwest Laboratory, Richland, Washington.

Sheridan, T. R., 1994a, Closure of the Ferrocyanide Unreviewed Safety Question, (letter 9401180/94-SST-052 to A. L. Trego, President, Westinghouse Hanford Company, March 4), U.S. Department of Energy, Richland Operations Office, Richland, Washington.

Sheridan, T. R., 1994b, Approval to Remove Two Ferrocyanide Tanks, 241-BX-102 and 241-BX-106, from the Watch List, (letter 9406684/94-SST-205 to A. L. Trego, President, Westinghouse Hanford Company, November 17), U.S. Department of Energy, Richland Operations Office, Richland, Washington.

Simmons, C. S., 1995, Modeling Water Retention of Tank Waste, PNL-10831, Pacific Northwest Laboratory, Richland, Washington.

Sloat, R. J., 1954, TBP Plant Nickel Ferrocyanide Scavenging Flowsheet, HW-30399, General Electric Company, Richland, Washington.

Sloat, R. J. 1955, In-Farm Scavenging Operating Procedure and Control Data, HW-38955, General electric Company, Richland, Washington.

Smith, D. A., 1986, Single-Shell Tank Isolation Safety Analysis Report, SD-WM-SAR-006, Rev. 2, Westinghouse Hanford Company, Richland, Washington. 
Wagoner, J. D., 1993, Approval of Hanford Site Tank Farm Facilities Interim Safety Basis, (letter 93-TOB-209 to T. M. Anderson, President, Westinghouse Hanford Company, November 18), U.S. Department of Energy, Richland Operations Office, Richland, Washington.

Watkins, J. D., 1991, Report to United States Congress on Waste Tank Safety Issues at the Hanford Site, (letter to D. Quayle, President of the Senate, July 16), U.S. Department of Energy, Washington, D.C.

Watson, W. T., 1993, Proof of Principle Report for In-Tank Moisture Monitoring Using an Active Neutron Probe, WHC-EP-0695, Westinghouse Hanford Company, Richland, Washington.

WHC, 1990, Operating Specifications for Watch List Tanks, OSD-T-151-00030, Rev. 0, Westinghouse Hanford Company, Richland, Washington.

WHC, 1991, Tank Farm Stabilization Plan for Emergency Response, WHC-SD-PRP-TI-001, Rev. 0, Westinghouse Hanford Company, Richland, Washington.

WHC, 1995, Operating Specifications for Watch List Tanks, OSD-T-151-00030, Rev. B-8, Westinghouse Hanford Company, Richland, Washington.

Wodrich, D. D., G. S. Barney, G. L. Borsheim, D. L. Becker, W. C. Carlos, M. J. Klem, R. E. Van der Cook, and J. L. Ryan, 1992, Summary of Single-Shell Waste Tank Stability, WHC-EP-0347, Supplement, Westinghouse Hanford Company, Richland, Washington.

Wood, S. A., 1992, Gas Space Analysis For Tank C-109, WHC-SD-WM-ER-183, Rev. 0, Westinghouse Hanford Company, Richland, Washington. 
This page intentionally left blank. 
WHC-EP-0474-18

\section{APPENDIX}

FERROCYANIDE TANK INFORMATION SUMMARY

A-1 
This page intentionally left blank. 
Table A-1. Summary of Contents and Status of Ferrocyanide Tanks."

\begin{tabular}{|c|c|c|c|c|c|c|c|}
\hline Tank & $\begin{array}{c}\text { Total waste } \\
\text { volume } \\
(1,000 \mathrm{~L})\end{array}$ & $\begin{array}{c}\mathrm{FeCN}^{\mathrm{b}} \\
(1,000 \mathrm{~g} \text {-mole })\end{array}$ & $\begin{array}{l}\text { Heat load } \\
(\mathrm{kW})^{\mathrm{c}}\end{array}$ & $\begin{array}{l}\text { Maxim } \\
\text { temf } \\
\left({ }^{\circ} \mathrm{C}\right)\end{array}$ & $\begin{array}{l}\text { mum } \\
\text { p. } \\
\left({ }^{\circ} \mathrm{F}\right)\end{array}$ & Riser No. & $\begin{array}{l}\text { Status of } \\
\text { tanks }\end{array}$ \\
\hline BY-103 & 1510 & 66 & 1.6 & $\begin{array}{l}27 \\
28^{\mathrm{e}}\end{array}$ & $\begin{array}{l}80 \\
83\end{array}$ & $\begin{array}{l}1 \\
5\end{array}$ & $\mathrm{NS} ; \mathrm{AL}$ \\
\hline BY-104 & 1540 & 83 & $3.3^{f}$ & $\begin{array}{ll}52^{\mathrm{e}} & 1 \\
45 & 1\end{array}$ & $\begin{array}{l}125 \\
112\end{array}$ & $\begin{array}{c}1 \\
10 \mathrm{~B}\end{array}$ & IS; Sound \\
\hline BY-105 & 1900 & 36 & $4.9^{f}$ & $\begin{array}{ll}48 & 1 \\
45 & 1\end{array}$ & $\begin{array}{l}118 \\
112\end{array}$ & $\begin{array}{c}1 \\
10 \mathrm{C}\end{array}$ & $\mathrm{NS} ; \mathrm{AL}$ \\
\hline BY-106 & 2430 & 70 & $4.7^{f}$ & 501 & 123 & 1 & $\mathrm{NS} ; \mathrm{AL}$ \\
\hline BY-107 & 1010 & 42 & 2.6 & $\begin{array}{l}36 \\
37^{\mathrm{e}}\end{array}$ & $\begin{array}{l}96 \\
98\end{array}$ & $\begin{array}{l}1 \\
5\end{array}$ & IS; AL \\
\hline BY-108 & 863 & 58 & 2.7 & $\begin{array}{ll}42^{\mathrm{e}} & 1 \\
42 & 1\end{array}$ & $\begin{array}{l}108 \\
107\end{array}$ & $\begin{array}{l}3 \\
8\end{array}$ & IS; AL \\
\hline BY-110 & 1510 & 71 & $3.3^{f}$ & $\begin{array}{ll}47 & 1 \\
41^{\circ} & 1\end{array}$ & $\begin{array}{l}116 \\
106\end{array}$ & $\begin{array}{c}1 \\
10 \mathrm{~A}\end{array}$ & IS; Sound \\
\hline BY-111 & 1690 & 6 & $2.1^{\mathrm{f}}$ & $28^{\circ}$ & 83 & 14 & IS; Sound \\
\hline BY-112 & 1100 & 2 & $2.4^{f}$ & $32^{e}$ & 90 & 2 & IS; Sound \\
\hline C-108 & 250 & 25 & $2.9^{f}$ & $\begin{array}{l}26^{e} \\
25\end{array}$ & $\begin{array}{l}80 \\
78\end{array}$ & $\begin{array}{l}1 \\
5\end{array}$ & IS; Sound \\
\hline C-109 & 250 & $6.8^{8}$ & $3.0^{f}$ & $\begin{array}{l}28^{e} \\
28\end{array}$ & $\begin{array}{l}83 \\
82\end{array}$ & $\begin{array}{l}3 \\
8\end{array}$ & IS; Sound \\
\hline $\mathrm{C}-111$ & 216 & 33 & $2.5^{f}$ & $\begin{array}{l}26 \\
24^{\circ}\end{array}$ & $\begin{array}{l}78 \\
76\end{array}$ & $\begin{array}{l}5 \\
6\end{array}$ & IS; AL \\
\hline $\mathrm{C}-112$ & 394 & $11.5^{\mathrm{g}}$ & $3.3^{\mathrm{f}}$ & $\begin{array}{l}29 \\
29^{\circ}\end{array}$ & $\begin{array}{l}85 \\
85\end{array}$ & $\begin{array}{l}1 \\
8\end{array}$ & IS; Sound \\
\hline $\mathrm{T}-107$ & 681 & 5 & $1.2^{\mathrm{f}}$ & $\begin{array}{l}20 \\
21^{\circ}\end{array}$ & $\begin{array}{l}67 \\
69\end{array}$ & $\begin{array}{l}4 \\
5\end{array}$ & NS; AL \\
\hline TX-118 & 1310 & $<3$ & 1.4 & $\begin{array}{l}23^{\circ} \\
24\end{array}$ & $\begin{array}{l}73 \\
76\end{array}$ & $\begin{array}{l}1 \\
3\end{array}$ & IS; Sound \\
\hline TY-101 & 447 & 23 & $1.1^{\mathrm{f}}$ & $\begin{array}{l}20^{\circ} \\
19\end{array}$ & $\begin{array}{l}68 \\
67\end{array}$ & $\begin{array}{l}3 \\
4\end{array}$ & IS; AL \\
\hline
\end{tabular}


Table A-1. Summary of Contents and Status of Ferrocyanide Tanks."

\begin{tabular}{|c|c|c|c|c|c|c|}
\hline Tank & $\begin{array}{c}\text { Total waste } \\
\text { volume } \\
(1,000 \mathrm{~L})\end{array}$ & $\begin{array}{c}\mathrm{FeCN}^{\mathrm{b}} \\
(1,000 \mathrm{~g} \text {-mole })\end{array}$ & $\begin{array}{c}\text { Heat load } \\
(\mathbf{k W})^{\mathbf{c}}\end{array}$ & $\begin{array}{l}\text { Maximum } \\
\text { temp. } \\
\left({ }^{\circ} \mathrm{C}\right)\left({ }^{\circ} \mathrm{F}\right)\end{array}$ & Riser No. & $\begin{array}{l}\text { Status of } \\
\text { tanks }\end{array}$ \\
\hline TY-103 & 613 & 28 & 1.5 & $\begin{array}{ll}22 & 71 \\
23^{\mathrm{e}} & 73\end{array}$ & $\begin{array}{l}4 \\
7\end{array}$ & IS; AL \\
\hline TY-104 & 174 & 12 & 0.9 & $\begin{array}{ll}20^{\circ} & 67 \\
20 & 68\end{array}$ & $\begin{array}{l}3 \\
4\end{array}$ & $\mathrm{IS} ; \mathrm{AL}$ \\
\hline
\end{tabular}

Table A-1 Notes:

- Reflects removal of four ferrocyanide tanks from the Watch List in July 1993 and two additional tanks in October 1994. Tank information and temperature data as of September 1995.

b Inventories from Borsheim and Simpson (1991).

: Heat load values from Table 7-1 in Crowe et al. (1993).

d IS - Interim Stabilized Tank; NS - Not Stabilized; AL - Assumed Leaker Tank; Sound - Non-Leaking Tank.

- Readings from new instrument trees; tank 241-BY-105 already had two trees.

f New data taken from Crowe et al. (1995).

- Calculated as ferrocyanide $\left[\mathrm{Fe}(\mathrm{CN})_{6}^{4}\right]$ based on the total cyanide values reported in Simpson et al. (1993a, 1993b). 
Table A-2. Ferrocyanide Tank Vapor Sampling Summary. (2 Sheets)

\begin{tabular}{|c|c|c|c|c|c|c|c|c|c|c|c|c|c|}
\hline Tank & $\begin{array}{c}\text { Date } \\
\text { Sampled } \\
\text { (Type)" }\end{array}$ & $\mid \begin{array}{c}\text { Flamm. } \\
\text { (\% LEL) }^{\mathrm{b}}\end{array}$ & $\begin{array}{c}\text { Organic } \\
\text { Vapor } \\
\text { (ppmv) }\end{array}$ & $\begin{array}{c}\mathrm{NH}_{3} \\
(\text { ppmv) }\end{array}$ & $\begin{array}{c}\mathrm{NH}_{3} \\
(\text { ppmv) }\end{array}$ & $\begin{array}{c}\text { HCN } \\
(\text { ppmv) }\end{array}$ & $\begin{array}{l}\mathrm{NO}+\mathrm{NO}_{2} \\
\text { (ppmv) }{ }^{\mathrm{d}}, \mathrm{s}\end{array}$ & $\begin{array}{l}\text { TNMOC } \\
\left(\mathrm{mg} / \mathrm{m}^{3}\right)^{f}\end{array}$ & $\begin{array}{c}\mathrm{H}_{2} \\
\left(\text { ppmv) }^{8}\right.\end{array}$ & $\begin{array}{c}\mathrm{N}_{2} \mathrm{O} \\
(\mathrm{ppmv})^{8}\end{array}$ & $\begin{array}{c}\mathrm{CO} \\
(\mathrm{ppmv})^{\mathrm{s}}\end{array}$ & $\begin{array}{c}\mathrm{CO}_{2} \\
(\mathrm{ppmv})^{\mathrm{g}}\end{array}$ & $\begin{array}{c}\text { Water } \\
\text { Content } \\
\text { \% RH }\left({ }^{\circ} \mathbf{C}\right)^{\mathrm{h}}\end{array}$ \\
\hline BY-103 & $\begin{array}{l}05 / 05 / 94(2) \\
11 / 01 / 94(3)\end{array}$ & $\begin{array}{l}<1 \\
. j\end{array}$ & $\begin{array}{l}1.2 \\
-\end{array}$ & 25 & $\begin{array}{l}30.7 \\
26\end{array}$ & $\begin{array}{c}<0.005^{1} \\
-\end{array}$ & $\begin{array}{l}<0.3 \\
<0.2\end{array}$ & $\begin{array}{l}5.2 \\
--\end{array}$ & $\begin{array}{l}21.4 \\
<99\end{array}$ & $\begin{array}{l}49.2 \\
16.5\end{array}$ & $\begin{array}{l}<1 \\
<12\end{array}$ & $\begin{array}{r}-- \\
126\end{array}$ & $49\left(25 . \overline{5}^{\circ} \mathrm{C}\right)$ \\
\hline$\overline{\text { BY-104 }}$ & $\begin{array}{l}04 / 22 / 94 \text { (2) } \\
06 / 24 / 94 \text { (3) }\end{array}$ & $\begin{array}{r}<1 \\
--\end{array}$ & $\begin{array}{r}26 \\
--\end{array}$ & $\begin{array}{r}200 \\
-\end{array}$ & $\begin{array}{l}285 \\
248\end{array}$ & $\begin{array}{c}<0.005^{1} \\
-\end{array}$ & $\begin{array}{l}<0.3 \\
<0.4\end{array}$ & $\begin{array}{l}56 \\
61\end{array}$ & $\begin{array}{l}204 \\
295\end{array}$ & $\begin{array}{l}305 \\
201\end{array}$ & $\begin{array}{r}<1 \\
1\end{array}$ & $\overline{10.5}$ & $58\left(26^{\circ} \mathrm{C}\right)$ \\
\hline BY-105 & $\begin{array}{l}05 / 09 / 94 \text { (2) } \\
07 / 07 / 94 \text { (3) }\end{array}$ & $<1$ & $\begin{array}{l}4.9 \\
-\end{array}$ & $\begin{array}{l}40 \\
-\end{array}$ & $\begin{array}{l}57 \\
43\end{array}$ & $\begin{array}{c}<0.005^{1} \\
-\end{array}$ & $\begin{array}{l}<0.1 \\
<0.2\end{array}$ & $\begin{array}{l}17.8 \\
12.7\end{array}$ & $\begin{array}{l}85 \\
48\end{array}$ & $\begin{array}{r}122 \\
50\end{array}$ & $\begin{array}{l}0.5 \\
0.4\end{array}$ & $\overline{94}$ & $61\left(26^{\circ} \mathrm{C}\right)$ \\
\hline BY-106 & $\begin{array}{l}05 / 04 / 94(2) \\
07 / 08 / 94 \text { (3) }\end{array}$ & $<1$ & 5.7 & 60 & $\begin{array}{l}87 \\
74\end{array}$ & $<0.01-$ & $\begin{array}{l}<0.2 \\
<0.2\end{array}$ & $\begin{array}{l}6.3 \\
9.9\end{array}$ & $\begin{array}{l}46 \\
46\end{array}$ & $\begin{array}{l}94 \\
71\end{array}$ & $\overline{0.5}$ & $\overline{47.6}$ & $57\left(27^{\circ} \mathrm{C}\right)$ \\
\hline BY-107 & $\begin{array}{l}03 / 25 / 94(2) \\
10 / 26 / 94(3)\end{array}$ & $\begin{array}{c}3-4 \\
-\end{array}$ & $\begin{array}{r}67 \\
-\end{array}$ & $\begin{array}{r}97 \\
-\end{array}$ & $\overline{972}$ & $\ddot{-}$ & $<\overline{0.2}$ & $\begin{array}{l}173 \\
150\end{array}$ & $\begin{array}{l}692 \\
267\end{array}$ & $\begin{array}{l}802 \\
621\end{array}$ & $\begin{array}{r}<5 \\
<20\end{array}$ & $\overline{94}$ & $36\left(33.1^{\circ} \mathrm{C}\right)$ \\
\hline BY-108 & $\begin{array}{l}03 / 28 / 94 \text { (2) } \\
10 / 27 / 94 \text { (3) }\end{array}$ & $\begin{array}{l}1 \\
--\end{array}$ & $\begin{array}{l}97 \\
-\end{array}$ & $\begin{array}{r}700 \\
-\end{array}$ & $\overline{1040}$ & $\begin{array}{l}-- \\
--\end{array}$ & $\begin{array}{l}<0.5 \\
<0.1\end{array}$ & $\begin{array}{l}594 \\
510\end{array}$ & $\begin{array}{l}644 \\
400\end{array}$ & $\begin{array}{l}757 \\
641\end{array}$ & $\begin{array}{r}<5 \\
<76\end{array}$ & $\overline{224}$ & $56\left(25 . \overline{7}^{\circ} \mathrm{C}\right)$ \\
\hline BY-110 & $\begin{array}{l}09 / 27 / 92(1) \\
11 / 11 / 94 \text { (3) }\end{array}$ & $\begin{array}{r}<1 \\
-\end{array}$ & $\begin{array}{r}350 \\
--\end{array}$ & $\begin{array}{r}612 \\
-\end{array}$ & $\overline{401}$ & $\begin{array}{l}<2 \\
--\end{array}$ & $\begin{array}{l}<0.5 \\
<0.2\end{array}$ & $\overline{29}$ & $<-\bar{c}$ & $\overline{103}$ & $<\overline{6}$ & $2 \overline{9}$ & $31\left(27^{\circ}{ }^{\circ} \mathrm{C}\right)$ \\
\hline BY-111 & $\begin{array}{l}05 / 11 / 94(2) \\
11 / 16 / 94(3)\end{array}$ & $\begin{array}{r}<1 \\
--\end{array}$ & $\begin{array}{l}8.9 \\
--\end{array}$ & $\begin{array}{r}60 \\
-\end{array}$ & 59 & - & $\overline{0.2}$ & $\overline{9.6}$ & $\overline{67}$ & 99 & $\begin{array}{l}<1 \\
<1\end{array}$ & $2 \overline{219}$ & $27\left(27^{\circ} \mathrm{C}\right)$ \\
\hline BY-112 & $\begin{array}{l}03 / 26 / 93(1) \\
11 / 18 / 94 \text { (3) }\end{array}$ & $\begin{array}{l}<1 \\
--\end{array}$ & $\begin{array}{l}5.9 \\
-\end{array}$ & 10 & $\overline{63}$ & $\begin{array}{l}<2 \\
--\end{array}$ & $\begin{array}{l}<0.5 \\
<0.2\end{array}$ & $\overline{5.8}$ & $<\overline{-}$ & $\overline{40}$ & $\overline{<12}$ & $\overline{121}$ & $53\left(23.3^{\circ} \mathrm{C}\right)$ \\
\hline C-108 & $\begin{array}{l}07 / 23 / 93 \text { (**) }^{* *} \\
07 / 07 / 94 \text { (2) } \\
08 / 05 / 94 \text { (3) }\end{array}$ & $\begin{array}{l}<1 \\
-- \\
--\end{array}$ & $\begin{array}{l}1.2 \\
- \\
-\end{array}$ & $\begin{array}{c}<2 \\
- \\
-\end{array}$ & $\begin{array}{l}\overline{-} \\
\overline{2.7}\end{array}$ & $\begin{array}{c}<2 \\
<0.0002^{i} \\
--\end{array}$ & $\begin{array}{c}<0.5 \\
-- \\
<0.3\end{array}$ & $\begin{array}{l}\quad \overline{0.4} \\
<1.4\end{array}$ & $\overline{15.3}$ & -- & $\begin{array}{l}1 \\
- \\
0.1\end{array}$ & $\begin{array}{l}-- \\
-- \\
16.3\end{array}$ & $\begin{array}{c}\overline{-} \\
\overline{-} \\
76\left(25^{\circ} \mathrm{C}\right)\end{array}$ \\
\hline \begin{tabular}{|c|c|c|}
$\mathrm{C}$ \\
\end{tabular} & $\begin{array}{l}06 / 23 / 94 \text { (2) } \\
08 / 09 / 94 \text { (3) }\end{array}$ & $\begin{array}{r}<1 \\
--\end{array}$ & $\begin{array}{l}1 \\
-\end{array}$ & $\begin{array}{l}4 \\
-\end{array}$ & $\overline{10.1}$ & $\overline{--}$ & $\overline{<0.6}$ & $\overline{0.65}$ & $\overline{125}$ & $\overline{--}$ & $\overline{0.4}$ & $\overline{3}$ & $79\left(27^{\circ} \mathrm{C}\right)$ \\
\hline C-111 & $\begin{array}{l}08 / 10 / 93\left(^{* *}\right) \\
06 / 20 / 94(2) \\
09 / 13 / 94(3)\end{array}$ & $\begin{array}{r}<1 \\
<1 \\
-.\end{array}$ & $\begin{array}{c}<0.2 \\
<0.2 \\
-\end{array}$ & $\begin{array}{l}<2 \\
<2 \\
-\end{array}$ & $\begin{array}{l}- \\
0.1 \\
5.6\end{array}$ & $\begin{array}{c}<0.04^{k} \\
<0.01^{i} \\
--\end{array}$ & $\begin{array}{l}<0.5 \\
<0.2 \\
\leq 0.7\end{array}$ & $\begin{array}{c}<0.3 \\
0.18 \\
<0.6\end{array}$ & $\begin{array}{l}16 \\
-\overline{12.4}\end{array}$ & $\begin{array}{l}39 \\
- \\
99\end{array}$ & $\begin{array}{l}0.1 \\
- \\
0.1\end{array}$ & $\overline{-}$ & $\begin{array}{c}-\overline{-} \\
\overline{-}\left(27^{\circ} \mathrm{C}\right)\end{array}$ \\
\hline C-112 & $\begin{array}{l}06 / 24 / 94 \text { (2) } \\
08 / 11 / 94 \text { (3) }\end{array}$ & $\begin{array}{r}<1 \\
-\end{array}$ & $\begin{array}{c}<0.2 \\
--\end{array}$ & $\begin{array}{l}4 \\
--\end{array}$ & $\overline{22.7}$ & $\begin{array}{l}-- \\
--\end{array}$ & $<\overline{0.7}$ & $\overline{3.4}$ & 204 & $\overline{544}$ & $\overline{0.9}$ & $\overline{-\overline{-}}$ & $82\left(28^{\circ} \mathrm{C}\right)$ \\
\hline T-107 & $\begin{array}{l}10 / 22 / 92(1) \\
01 / 18 / 95 \text { (3) }\end{array}$ & $\begin{array}{l}<1 \\
--\end{array}$ & 24 & $\begin{array}{r}203 \\
--\end{array}$ & $\overline{--}$ & $\begin{array}{l}<2 \\
--\end{array}$ & $\begin{array}{l}<0.5 \\
<0.1\end{array}$ & $\begin{array}{l}-- \\
1.4\end{array}$ & $<\overline{-}$ & $\overline{42}$ & $<\overline{12}$ & $\overline{75}$ & $82\left(17 . \overline{2}^{\circ} \mathrm{C}\right)$ \\
\hline
\end{tabular}


Table A-2. Ferrocyanide Tank Vapor Sampling Summary. (2 Sheets)

\begin{tabular}{|c|c|c|c|c|c|c|c|c|c|c|c|c|c|}
\hline Tank & $\begin{array}{c}\text { Date } \\
\text { Sampled } \\
\text { (Type) }\end{array}$ & $\begin{array}{l}\text { Flamm. } \\
(\% \text { LEL })^{b}\end{array}$ & $\begin{array}{l}\text { Organic } \\
\text { Vapor } \\
\text { (ppmv) }^{c}\end{array}$ & $\begin{array}{c}\mathrm{NH}_{3} \\
(p p m v)^{d}\end{array}$ & $\begin{array}{c}\mathrm{NH}_{3} \\
(\text { ppmv) }\end{array}$ & $\begin{array}{c}\text { HCN } \\
(p p m v)^{d}\end{array}$ & $\begin{array}{l}\mathrm{NO}+\mathrm{NO}_{2} \\
\left(\text { ppmv) }{ }^{\mathrm{d}}\right.\end{array}$ & $\begin{array}{l}\text { TNMOC } \\
\left(\mathrm{mg} / \mathrm{m}^{3}\right)^{\mathrm{f}}\end{array}$ & $\begin{array}{c}\mathrm{H}_{2} \\
(p p m v)^{8}\end{array}$ & $\begin{array}{c}\mathrm{N}_{2} \mathrm{O} \\
(\text { ppmv })^{8}\end{array}$ & $\begin{array}{c}\mathrm{CO} \\
(\text { ppmv) }\end{array}$ & $\begin{array}{c}\mathrm{CO}_{2} \\
(\text { ppmv })^{\mathrm{s}}\end{array}$ & $\begin{array}{c}\text { Water } \\
\text { Content } \\
\text { \% RH }\left({ }^{\circ} \mathbf{C}\right)^{k}\end{array}$ \\
\hline TX-118 & $\begin{array}{c}07 / 28 / 93 \text { (**) } \\
09 / 07 / 94 \text { (2) } \\
12 / 16 / 94 \text { (3) }\end{array}$ & $\begin{array}{l}<1 \\
<1 \\
-\end{array}$ & $\begin{array}{l}0.3 \\
7.8 \\
--\end{array}$ & $\begin{array}{l}10 \\
28 \\
-\end{array}$ & $\overline{33}$ & $\begin{array}{c}<2 \\
<0.02 \\
-\end{array}$ & $\begin{array}{c}<0.5 \\
<0.5 \\
--\end{array}$ & $\begin{array}{l}- \\
9.3 \\
--\end{array}$ & $\begin{array}{r}- \\
97 \\
<94\end{array}$ & $\begin{array}{l}-- \\
17 \\
29\end{array}$ & $\begin{array}{r}- \\
2.5 \\
<12\end{array}$ & $\begin{array}{l}\overline{54} \\
98\end{array}$ & $\begin{array}{c}-- \\
-- \\
42\left(21.5^{\circ} \mathrm{C}\right)\end{array}$ \\
\hline TY-101 & $\begin{array}{l}08 / 04 / 94(2) \\
04 / 06 / 95(3)\end{array}$ & $\begin{array}{r}<1 \\
-.\end{array}$ & $\begin{array}{l}4 \\
--\end{array}$ & $\begin{array}{l}12 \\
--\end{array}$ & $\begin{array}{l}16 \\
16\end{array}$ & $\begin{array}{c}<0.01 \\
--\end{array}$ & $\begin{array}{l}<0.2 \\
<0.2\end{array}$ & $\overline{-}-\overline{1.0}$ & $<\overline{-}$ & 98 & $<\overline{12}$ & $\overline{83}$ & $77\left(15.6^{\circ} \mathrm{C}\right)$ \\
\hline TY-103 & $\begin{array}{l}08 / 04 / 94(2) \\
04 / 11 / 95(3)\end{array}$ & $\begin{array}{r}<1 \\
--\end{array}$ & $\begin{array}{l}5 \\
--\end{array}$ & 30 & $\begin{array}{l}31 \\
49\end{array}$ & $\begin{array}{c}<0.01 \\
-\end{array}$ & $\begin{array}{l}<0.1 \\
<0.2\end{array}$ & $\overline{60}$ & $<93$ & 159 & $<\overline{12}$ & $1 \overline{-}$ & $85\left(15.9^{\circ} \mathrm{C}\right)$ \\
\hline TY-104 & $\begin{array}{l}08 / 05 / 94(2) \\
04 / 27 / 95(3)\end{array}$ & $\begin{array}{l}<1 \\
-\end{array}$ & $\begin{array}{l}2.5 \\
--\end{array}$ & $\begin{array}{r}24 \\
-\end{array}$ & $\begin{array}{l}50 \\
61\end{array}$ & - & $\begin{array}{l}<0.2 \\
\leq 0.2\end{array}$ & $\overline{3}$ & $<\overline{49}$ & $\overline{98}$ & $<\overline{23}$ & $<\overline{23}$ & $88\left(15.6^{\circ} \mathrm{C}\right)$ \\
\hline
\end{tabular}

Sample Type:

** Vapor samples taken from in-tank, non-heated tubes using a vapor sampling cart (SUMMA ${ }^{\mathrm{TM}}$ only - no $\mathrm{NH}_{3}$ ).

1 Monitoring performed by Industrial Hygiene technicians using three varying length, non-heated sampling tubes into the tank headspace to evaluate for flammability and toxic vapors; this method is no longer used.

2 In Situ Sampling (ISS) - Sampling is performed by lowering special sorbent traps into the tank headspace that are connected topside to a portable handcart.

3 Sampling involves the mobile vapor sampling system (VSS), heated transfer lines, and installation of a water-heated sampling probe into the tank headspace. All ferrocyanide tanks are scheduled for resampling using this method.

b Measured using a combustible gas meter; LEL = Lower Explosive Limit.

- Measured using an Organic Vapor Monitor (OVM). OVM readings are affected by ammonia; OVM ammonia

response is about 13:1, so that $13 \mathrm{ppmv}$ of ammonia is indicated as $1 \mathrm{ppmv}$ of organic vapors (ppmv = parts per million by volume).

- For Type 1 sampling only; value is measured using colorimetric (Dräger ${ }^{\mathrm{MM}}$ ) tubes (values are estimated, and not quantitative).

- Analyses of ammonia sorbent trap samples.

f Total non-methane organic compound (TNMOC) concentrations measured for SUMMA ${ }^{\mathrm{TM}}$ canister samples.

8 Analyses of SUMMA ${ }^{\mathrm{TM}}$ canister samples from Type **, and 3 sampling methods.

b \% $\mathrm{RH}$ is the percent relative humidity calculated from measured headspace water content $(\mathrm{mg} / \mathrm{L})$, temperature and atmospheric pressure. Temperature of headspace gas in ${ }^{\circ} \mathrm{C}$ is listed in parentheses.

i HCN determinations obtained in selected tanks using a special sorbent trap; values shown are below detection limit of the measurement technique.

$j$-- Data not yet available or not obtained by this type of sampling.

${ }^{1}$ This HCN number was $<0.04$ parts per billion vapor as determined by a special sodium hydroxide bubbler. 


\section{APPENDIX REFERENCES}

Borsheim, G. L., and R. J. Cash, 1991, Unusual Occurrence - Addition of Two Tanks to List of Unreviewed Safety Question Tanks Containing Ferrocyanide, WHC-91-0096-TFARM, February 13, Westinghouse Hanford Company, Richland, Washington.

Crowe, R. D., M. Kummerer, and A. K. Postma, 1993, Estimation of Heat Load in Waste Tanks Using Average Vapor Space Temperatures, WHC-EP-0709, Westinghouse Hanford Company, Richland, Washington.

Crowe, R. D., D. P. Maassen, and S. A. Parra, 1995, Calculated Heat Load for Watchlist Single-Shell Waste Tanks Using the Average Vapor Space Temperatures, (letter report attached to internal memorandum from H. Toffer to R. J. Cash, September 29), Westinghouse Hanford Company, Richland, Washington.

Simpson, B. C., G. L. Borsheim, and L. Jensen, 1993a, Tank Characterization Report: Tank 241-C-109, WHC-EP-0688, Westinghouse Hanford Company, Richland, Washington.

Simpson, B. C., G. L. Borsheim, and L. Jensen, 1993b, Tank Characterization Data Report: Tank 241-C-112, WHC-EP-0640, Rev. 1, Westinghouse Hanford Company, Richland, Washington. 
This page intentionally left blank. 


\section{DISTRIBUTION}

Number of copies

OFFSITE

U.S. Department of Energy

EM-36, Trevion II

12800 Middlebrook Road

Germantown, MD 20874

James V. Antizzo, EM-36

Charles O'Dell, EM-36 (5)

U.S. Department of Energy

Forrestal Building

1000 Independence Avenue SW

Washington, DC 20585

Shirley Campbell, EH-71

John Kaysak, EM-25

1

Charles S. Abrams

1987 Virginia

Idaho Falls, ID 83404

1

David O. Campbell

102 Windham Road

Oak Ridge, TN 37830

1

Fred N. Carlson

6965 North 5th West

Idaho Falls, ID 83401

1

Billy C. Hudson

202 Northridge Court

Lindsborg, KA 67456

1

Air Products \& Chemicals. Inc. 7201 Hamilton Blvd Allentown, PA 18195-1501

George E. Schmauch 


\section{DISTRIBUTION (Continued)}

Number of copies

OFFSITE

$\cdot 1$

Brookhaven National Laboratory

Upton, NY 11973

Kamal K. Bandyopadhyay

2

Fauske and Associates, Inc.

16W070 W. 83rd St.

Burr Ridge, IL 60521

Michael Epstein

Hans K. Fauske

2

G \& P Consulting. Inc. 3640 Ballard Road

Dallas, OR 97338

J. Michael Grigsby

Arlin K. Postma

1

Harvard University 295 Upland Avenue

Newton Highlands, MA 02161

Melvin W. First

2

Los Alamos National Laboratory

P.O. Box 1663

Los Alamos, NM 87545

Steve F. Agnew

Thomas E. Larson 


\section{DISTRIBUTION (Continued)}

Number of copies

\section{OFFSITE}

MIT/Department of Nuclear Engineering

77 Massachusetts Ave.

Room 24-102

Cambridge, MA 02139

Mujid S. Kazimi

1

Nuclear Consulting Services, Inc.

P.O. Box 29151

Columbus, $\mathrm{OH} \quad 43229-0151$

J. Louis Kovach

Oak Ridge National Laboratory

1

Emory D. Collins

P.O. Box 2008

7930, MS-6385

Oak Ridge, TN 37831-6385

1

Charles W. Forsberg

P.O. Box 2008

MS-6495

Oak Ridge, TN 37831-6495

1

Thomas S. Kress

102-B Newridge Road

Oak Ridge, TN 37839

1

Rice University

5211 Paisley

Houston, TX 77096

Andrew S. Veletsos 
Number of copies

\section{DISTRIBUTION (Continued)}

\section{QFFSITE}

2

Sandia National Laboratories

P.O. Box 5800

Albuquerque, NM 87185

Dana A. Powers, MS-0744

Scott E. Slezak, MS-0741

3

Science Applications International Corporation

20300 Century Blvd, Suite 200-B

Germantown, MD 20874

Ray S. Daniels (3)

State of Washington - Department of Ecology

1

Robert C. King

P. O. Box 47600

Olympia, WA $98504-7600$

1

Alex B. Stone

1315 W. 4th Avenue

Kennewick, WA 99336

1

Waste Policy Institute

555 Quince Orchard Road, Suite 600

Gaitherburg, MD 20878-1437

Donald T. Oakley

ONSITE

10

U.S. Department of Energy, Richland Operations Office

R. E. Gerton

S7-54

R. G. Harwood

S7-54

W. F. Hendrickson (2)

S7-54

D. H. Irby (2)

S7-54 


\section{DISTRIBUTION (Continued)}

M. F. Jarvis

S7-54

A. G. Krasopoulos

A4-81

Public Reading Room

H2-53

RL Docket File (2)

B1-17

Pacific Northwest Laboratory

J. W. Brothers

K5-22

R. T. Hallen

P8-38

M. A. Lilga

P8-38

C. S. Simmons

K9-33

Hanford Technical Library

P8-55

Westinghouse Hanford Company

H. Babad

S7-30

J. B. Billetdeaux

S7-16

W. S. Callaway

S3-90

R. J. Cash (5)

S7-15

M. D. Crippen

L5-31

R. D. Crowe

H0-38

D. R. Dickinson

L5-31

G. T. Dukelow

S7-15

M. N. Islam

R3-08

D. W. Jeppson

L5-31

N. W. Kirch

R2-11

C. A. Kuhlman

B3-30

L. L. Lockrem

S3-90

J. M. McLaren

H0-34

J. E. Meacham (2)

S7-15

N. J. Milliken

H4-65

S. R. Moreno

B3-06

T. V. Rebagay

T6-30

F. R. Reich

L5-55

E. F. Riedel

S3-90

B. C. Simpson

R2-12

W. T. Watson

H0-38

W. D. Winkelman

L5-55

W. D. Wittekind

H0-38 


\section{DISTRIBUTION (Continued)}

Central Files

Correspondence Processing EDMC

OSTI (2)
A3-88

R1-20

H6-08

A3-36 